\title{
Thirteen years of Operations Management Research (OMR) journal: a bibliometric analysis and future research directions
}

\author{
Mohamed M. Dhiaf ${ }^{1} \cdot$ Osama F. Atayah ${ }^{2} \cdot$ Nohade Nasrallah $^{3} \cdot$ Guilherme F. Frederico $^{4}$ (D)
}

Received: 15 April 2021 / Revised: 5 June 2021 / Accepted: 18 June 2021 / Published online: 2 July 2021

(c) The Author(s), under exclusive licence to Springer Science+Business Media, LLC, part of Springer Nature 2021

\begin{abstract}
The journal of Operations Management Research (OMR) is a rigorous journal that started its publication in 2008. It publishes short, focused research studies that advance both the theory and practice of operations management. Considering the relevant OMR's contribution to the field of Operations Management in the last years, this study provides an overall assessment of the journal performance by conducting a retrospective review. To elaborate on OMR's temporal development in terms of publications, authors, affiliated institutions and countries, citation patterns, and conceptual structure, we extract publications from Scopus database for the period 2008-2020. We rely on bibliometric techniques in addition to bibliographic coupling, keyword analysis, and content analysis. 166 documents were analyzed using RStudio, VOSviewer, and Microsoft Excel. Findings emphasize OMR's steady productivity growth (3.24\%). Narrowly, Olhager J. is the most productive authors while Kalchschmidt M. and Stentoft J. are the most influential authors (H-index of 4). Furthermore, USA contributes to the highest number of publications while UK is the most influential country in terms of citations. Cranfield School of Management, UK stands as the top cited university. The analysis of the thematic evolution concludes to three main clusters: "Manufacturing and Supply chain Performance", "Six Sigma and Lean Management", and "Reshoring, Backshoring and Offshoring". This study recommends to further investigate the implications of the fourth industrial revolution and the sequels of COVID-19.
\end{abstract}

Keywords Journal analysis $\cdot$ Operations management $\cdot$ Research $\cdot$ Bibliometric $\cdot$ Scientometric $\cdot$ Research directions

\section{Introduction}

Operations research and management science has amplified in the scientific community since the official establishment of the Operations Research Society of America (ORSA) in 1952, the Operational Research Society (ORS) of the United

Guilherme F. Frederico

guilherme.frederico@ufpr.br

Mohamed M. Dhiaf

dhiafmohamed@yahoo.fr

Osama F. Atayah

Dr.osamaatayah@gmail.com

Nohade Nasrallah

nnasrallah@ndu.edu.lb

1 Faculty of Business Administration, Emirates College of Technology - ECT, Abu Dhabi, UAE

2 College of Business, Abu Dhabi University, Abu Dhabi, UAE

3 Faculty of Management \& Economics, Notre Dame University, Beirut, Lebanon

4 School of Management, Federal University of Paraná UFPR, Curitiba, Brazil
Kingdom in 1953 and The Institute of Management Sciences (TIMS) in 1953 (Merigó et al. 2019). Originally, it sought to embrace the industrial and manufacturing methods and procedures (Buffa 1980), and has then expanded to permeate service systems and a myriad of functional organizational areas such as marketing, accounting, purchasing/ logistics, information management, engineering and human resources (Craighead and Meredith 2008). In as much, the field evolved with time and merged from relatively high reliance on mathematical techniques to more sophisticated ones. Such diversely and wealthy discipline contributed to OR journals' surge that attracted many scholars and analysts. Among them, Operations Management Research (OMR) that was launched as a hybrid and transformative journal aiming to publish original, high-quality research that are shorter and more sharply focused than existing Operational Management (OM) ones. The journal started publication in 2008 in Springer New York L.L.C, United States and provided relevant contributions to the field of operations management, being one of the most outlets sought by researchers. Its expansive and wealthy scope engendered many multidisciplinary approaches and robust conceptual integration such as: "Industrial and 
Manufacturing Engineering", "Management of Technology and Innovation", "Management Sciences and Operations Research" and "Strategy and management". Its current editors are Matteo Kalchschmidt, and Daniel A. Samson.

As $\mathrm{OM}$ is a functional field with enormous strides in the last decades, OMR flourished in both publication activities and citations. Though it is a young journal, it succeeded to be included in Thomson Reuters ISI Web of Knowledge in 2012 and managed to position itself well among the operations management journals, promoting research that is relevant to both practitioners and researchers (Olhager and Shafer 2018). This reflects its impactful presence and continual prominence as it is targeted by prolific researchers who kept on promoting its excellent intellectual base and disseminating knowledge. According to SCImago Journal Rank (SJR), this journal is ranked 1.313 and has an $\mathrm{H}$-index of 18 . The best quartile for this journal is Q1 and its best quartile by subject area is Industrial and Manufacturing Engineering (Q1), Management of Technology and Innovation (Q1), Management Sciences and Operations Research (Q1) and Strategy and management (Q1). OMR has total citations of 3,033 . Its overall rank is 2,855 and its impact factor is 5.95 .

Factually, the publication quest to target top ranking journals is a major sticking point where common metrics are used to assess overall journal quality and find the suitable niche. Journal Impact Factor (JIF) is one of the most used metrics. It is a measure of the frequency with which the average article in a journal has been cited in a particular year. However, many journals/authors self-cite their own articles. Actuality, journal quality is assessed by three main factors: citation analysis, peer analysis (reviewer selection criteria), and circulation and coverage (international audience and electronic copies). Yet besides the fact that such criteria should be collectively considered, scholars should account for other factors such as: relative thickness and frequency of publication, co-authorship, thematic trends and co-occurrence, and acceptance/rejection rates.

In 2019 editorial, 14 hot topic areas were recommended in operations and supply chain management $(\mathrm{O} / \mathrm{SCM})$ that deserve scholars' attention and practical work (Samson and Kalchschmidt 2019). Much more, in 2020 editorial, Samson (2020) drew on major changes in O/SCM context and the consequential disruptions caused by COVID-19 as the pandemic effect has touched macro and microeconomic levels. New mitigating strategies are proposed to reduce reliance on long international supply chains that lead to reconsider reshoring and other risk mitigation strategies. Thus, the journal transcendental and reversal changes are worth commenting and based to our knowledge, prior studies to assess OMR's performance are not conducted yet. In parallel, the emergence of scientific databases such as Scopus and Web of Science has facilitated the acquisition of large data to pursue a complete bibliometric analysis in addition to the powerful software such as VOS and Biblioshiny (R studio) that permit to objectively perform quantitative analysis to decipher and map the cumulative scientific knowledge.

To cope with the above gaps, we conduct this study to analyze OMR history, benchmark it and highlight its performance. In this sense other studies were previously conducted in order to understand the journal development and provide readers with rich and valuable information (Rialp et al. 2019; Wang et al. 2019; Kumar et al. 2020a, b). Also, some specific areas have been thoroughly explored such as: Entrepreneurship (Moya-Clemente et al. 2021; Servantie et al. 2016); Knowledge Management (Zha et al. 2020; Noor et al. 2020); Operations Management (Pilkington and Meredith 2018; Laengle et al. 2017; Liao et al. 2019; Caputo et al. 2019; Schulz and Nicolai 2015; Oliveira et al. 2018).

Therefore, our analysis aims to highlight OMR's high reputation and its extensive contribution where we draw on its influential impact, relevant insights, ongoing changes, future direction, and innovative methodologies. It is an indepth analysis of the annual citation structure and trend along with an inter-temporal analysis its focus and attempts to anticipate potential developments and new research paths. It provides insights into the journal's past, present and future trends by offering a retrospective analysis of the journal's content (Laengle et al. 2017). It addresses the following research questions: (1) What is OMR publications and citations trend over the last 13 years? (2) Which are OMR top-cited papers? (3) Who are the most productive and influential authors, institutions, and countries? (4) What are OMR thematic patterns? (5) Which are the persistent, hot, and cold topics?

We aim to achieve the following objectives: (1) shed light on OMR major theoretical and empirical contributions, (2) identify top and most influential scholars in terms of journals, countries and affiliations, (3) describe co-authorship relations and collaboration status in order to highlight their preponderance to curb citation trends, (4) benchmark OMR to build its competitive capabilities in terms of technology, quality, delivery, and productivity (Dertouzos et al. 1989; Hines et al. 1998), (5) provide hot topics and develop future directions in OR by revealing the current research trends and frontiers of various disciplines through keywords and co-citation analyses, (6) map and visualize results to have more intuitive presentation, and (7) pinpoint OMR critical issues and motivational strategies to further improve its ranking and visibility. Thus, this paper provides a comprehensive and broad review that encourages the scientific community and researchers in OR to engage in further discussions.

As the methodological support, we have used VOSviewer, $\mathrm{R}$ studio, and Microsoft Excel to derive insightful metrics to assess OMR influential impact, benchmark it relatively to 
peer journal in the same field and analyze its performance and temporal development.

The organization of this paper is as follows. Section 2 introduces the study's methodology, while Sect. 3 reports the results, which are divided into three major parts (publication analysis, citation analysis and network analysis). Section 4 provides the content analysis of each cluster. Section 5 provides a future agenda and Sect. 6 concludes to a summary of findings.

\section{Methodology}

The bibliometric analysis is gaining popularity as it is commonly used to analyze and evaluate the performance of scientific community in specific knowledge area (Barber and Mancall 1978; Bookstei 1979; Ferrante 1978). It becomes a fundamental tool to weigh the research impact and depict patterns of scientific contribution. To track the evolution of OMR and to identify yearly trends, we apply quantitative analysis to facilitate our interpretation. The bibliometric analysis leverages the authors' ability to manage, analyze, and extract insights from massive data, including intellectual structure, influential actors and contributors, as well as authors (Zagos and Brad 2012), affiliations (Boardman 2008), countries (Rey-Martí et al. 2016) sources, (Loh and Venkatraman 1992), and references (Tang et al. 2020). In addition, bibliometric approach is helpful to accurately identify the quantitative and qualitative indicators to develop reliable and relevant knowledge structure (Fagerberg et al., 2012).

Specifically, in the domain of journals' performance analysis, the bibliometric analysis has been commonly used in several studies to analyze different journals in various discipline; for instance Finance (Baker et al. 2021; Linnenluecke et al. 2020; Paule-Vianez et al. 2020); Accounting (Martínez-Blasco et al. 2016; Muehlmann et al. 2015; Yamaguchi et al. 2015); Management (Mishra et al. 2018), and Economic (Goyal et al. 2021).

To analyze OMR's performance, we consulted the Scopus database and extracted 166 published documents over 13 years (2008 to 2020). They consist of 149 articles, 16 editorials, and 1 erratum (Table 1). Despite that this data was manually refined and cleaned to avoid the risk of redundant author and affiliations names, it is still possible to have some duplicated data due to various types of writings and spelling. The study employs several bibliometric indicators to provide a comprehensive view and insightful analysis. First, the VOSviewer was employed to carry the mapping analysis, bibliographic coupling, keyword cooccurrences analysis, and co-authorship. VOSviewer is an efficient software that constructs and visualizes bibliometric networks for scientific actors, such as authors, journals, affiliation, citations, countries and other aspects (Chygryn et al. 2020; Evans 2019; Ferasso et al. 2020). Second, R
Table 1 OMR overview between 2008 and 2020

\begin{tabular}{ll}
\hline Journal Overview 2008-2020 & \\
\hline Panel 1: Descriptive statistics & 166 \\
Documents & 18.27 \\
Average citations per documents & 2.121 \\
Average citations per year per doc & 8193 \\
References & 18 \\
H-index & \\
Panel 2: Document types & 149 \\
Article & 16 \\
Editorial & 1 \\
Erratum & \\
Panel 3: Authors' collaboration & 19 \\
Single-authored documents & 373 \\
Multiple-authored documents & 0.423 \\
Documents per Author & 2.36 \\
Authors per Document & 2.75 \\
Co-Authors per Documents & 2.54 \\
Collaboration Index & \\
\hline
\end{tabular}

studio has been applied to analyze several aspects, including the conceptual structure, productivity, most influential scientific actors, Lotka's law, and topics trend.

Along with descriptive analysis, the study identifies the thematic structure of the journal using bibliometric coupling analysis. Kessler (1963) proposes that documents citing an identical third document tend to form a bibliographic couple and that bibliographic couples discuss similar intellectual themes (Martyn 1964).

The count of publications is the measure of productivity and the count of citations is the measure of influence (Kumar et al. 2020a, b). Specifically, we have used "biblioshiny" package, which consists of tools designed for quantitative studies in the field of both bibliometric and scientometrics. This package is helpful in converting the dataset into $\mathrm{R}$ format, carrying accurate bibliometric analysis, and developing matrices for various aspects, including co-citation, scientific actors' collaboration, words analysis, and multiple correspondence analyses. Third and finally, Microsoft Excel was used to develop editable figures and tables, and to verify several tests such as citations, journal productivity, and affiliation production.

\section{Results}

Bibliometric data and analysis provide information on the scientific orientation and dynamism of a journal, and on its impact on both the national and the international community 
(Okubo 1997). It uses numerous parameters such as: (1) performance analysis and (2) sciences mapping. The performance analysis serves to depict journal constituents' performance (authors, affiliations, and countries) while the sciences mapping addresses constituents' relationship. The below part provides a thorough analysis of the journal productivity, performance, benchmarking, and citation analyses.

\subsection{Performance analysis and benchmarking}

Benchmarking is an important strategic tool that reflects a qualitative orientation toward journals performance. It identifies future research to achieve a more systematic and quantitative analysis conducive to sharing a base of knowledge. Over the past 13 years, OMR productivity noticeably grew and contributed to 166 articles in the operations management discipline with an emphasis on contemporary issues that enhanced the industry efficiencies. It has an $\mathrm{H}$-index of 28 which indicates that 28 papers have each received 28 citations or more. This measure is useful because it considers both the quality and the quantity of a set of publications. OMR earned 3,033 citations over 13 years and averaged 18.27 citations per document. The journal realized $3.24 \%$ annual growth rate over its lifespan which implicates a steady growth in the number of publications. Its collaboration index is 2.54 which suggests that each author cooperates with more than 2 authors to contribute a research work in the journal. It showcases the need for technical and scientific cooperation between scholars from different countries, universities, and backgrounds.

\subsubsection{Distribution of publications over years}

In this section, we provide a detailed overview of OMR temporal activity to measure the volume and impact of OMR research over prolonged periods of time as a means of identifying trends. Figure 1 visualizes the yearly publication trend. At its early beginning (2008-2012), the journal witnessed a volatile productivity depicted in a peak in 2010 (18 publications) and a trough in 2009 (8 publications). Over the subsequent 5 years (2013-2017), the publication trend was steady with an average of 11 publications per year. The last three years were remarkable as OMR productivity rate jumped by $71.43 \%(2018-2019)$ and then by $83.33 \%$ (2019-2020). The last year (2020) was exceptional with a striking increase in OMR productivity that led to the publication of the third issue. Moreover, the average publication per issue ranges between 5 and 8 . Two exceptions are worth commenting. In 2010, the average publication per issue was the highest (9) while in 2018 this average was at its lowest level (3.5). 52\% of total publication took place in the first issue publication while the remaining $48 \%$ are published in the second one.

\subsubsection{Most relevant scientific actors (authors, affiliations, \& countries)}

The below section gathers a variety of dimensional indicators that analyze the number of publications, citations, and authors production over time. Table 2 shows the top 20 authors in terms of different metrics. The number of publications measures the academic contributions of OMR, the standard forms of influence and impact such as the h-index, g-index, and m-index (Egghe and Rousseau 2006; Hirsch 2005). Broadly, the $h$-index (h) indicates $h$ number of publications cited at least $\mathrm{h}$ times, the g-index ( $\mathrm{g}$ ) accounts for the $\mathrm{g}$ number of highly cited publications receiving at least $g^{2}$ citations. While, h-index is independent of the date of an academic's career, the m-index aims at weighing the period of academic endeavor so to reduce the bias in favor of scientists with longer careers. Thus, if $n=$ number of years since the first published paper of the scientist, the
Fig. 1 OMR's yearly publication by issue between 2008 and 2020

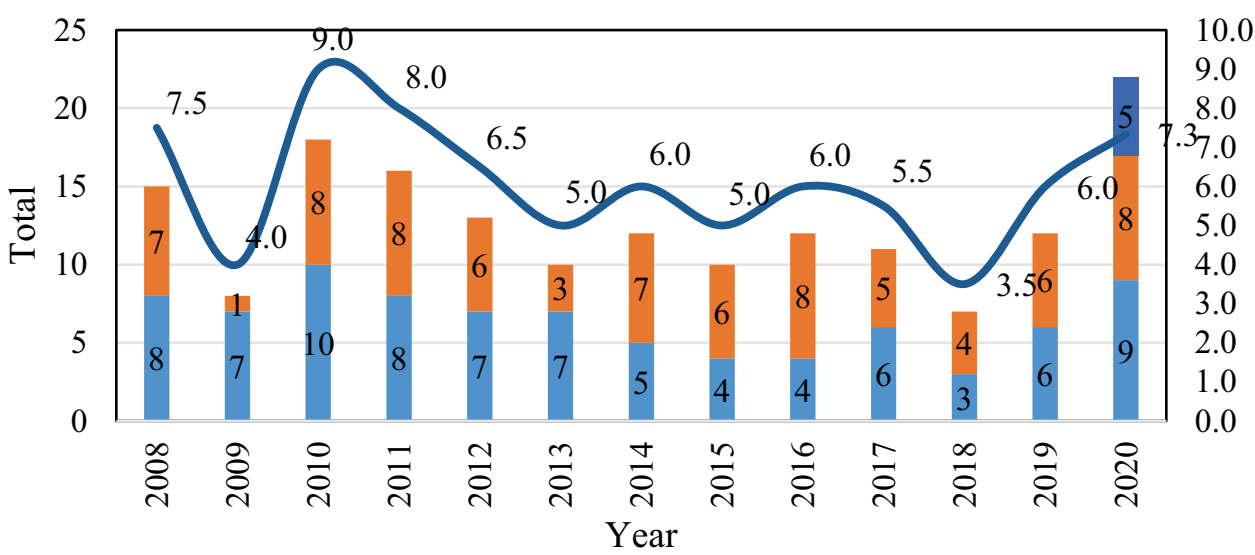

issue $1 \quad$ issue $2 \simeq$ In press $\quad$ Average 
Table 2 Top 20 Authors in terms of publications and citations

\begin{tabular}{lllllllll}
\hline Order & Author & $\begin{array}{l}\text { Number of } \\
\text { publications }\end{array}$ & H_index & G_index & M_index & PY_start & Citations & $\begin{array}{l}\text { Citations } \\
\text { per publica- } \\
\text { tion }\end{array}$ \\
\hline 1 & & & & & & & & 10 \\
2 & Olhager J & 7 & 2 & 7 & 0.143 & 2008 & 70 & 0.4 \\
3 & Shafer S & 5 & 1 & 1 & 0.1 & 2012 & 2 & 29 \\
4 & Holmstrm J & 4 & 3 & 4 & 0.3 & 2012 & 116 & 12.5 \\
5 & Kalchschmidt M & 4 & 4 & 4 & 0.286 & 2008 & 50 & 30.25 \\
6 & Stentoft J & 4 & 4 & 4 & 0.5 & 2014 & 121 & 8.33 \\
7 & McDermott CM & 3 & 2 & 3 & 0.182 & 2011 & 25 & 2 \\
8 & Meredith JR & 3 & 1 & 2 & 0.071 & 2008 & 6 & 2 \\
9 & Samson D & 3 & 2 & 2 & 0.071 & 2008 & 6 & 4.67 \\
10 & Singh PJ & 3 & 3 & 3 & 0.3 & 2012 & 19 & 6.33 \\
11 & Vinelli A & 3 & 3 & 3 & 0.231 & 2009 & 122 & 40.67 \\
12 & Neely A & 2 & 2 & 2 & 0.143 & 2008 & 719 & 359.5 \\
13 & Akhtar N & 2 & 1 & 2 & 0.333 & 2019 & 16 & 8 \\
14 & Bals L & 2 & 2 & 2 & 0.333 & 2016 & 69 & 34.5 \\
15 & Barbieri P & 2 & 2 & 2 & 0.333 & 2016 & 22 & 11 \\
16 & Bengtsson L & 2 & 1 & 2 & 0.083 & 2010 & 30 & 15 \\
17 & Boakye KG & 2 & 2 & 2 & 0.2 & 2012 & 23 & 11.5 \\
18 & Boffelli A & 2 & 2 & 2 & 1 & 2020 & 11 & 5.5 \\
19 & Cagliano AC & 2 & 2 & 2 & 0.4 & 2017 & 14 & 7 \\
20 & Caniato F & 2 & 2 & 2 & 0.143 & 2008 & 42 & 21 \\
\hline & & 3 & 3 & 0.667 & 2019 & 14 & \\
\hline
\end{tabular}

This table ranks the 20 most prolific OMR authors in terms of citations between 2008 and 2020. where $\mathrm{H}$-Index $=$ number of papers $(\mathrm{N})$ with $\mathrm{N}$ citations or more, G-Index $=$ number of articles that have accumulated $\mathrm{g}^{2}$ number of citations, $\mathrm{M}$-index $=\mathrm{H}$-index per active year for the author and PY_start = start of the publication year m-quotient $=\mathrm{h}$-index $/ n$. We also account for citation per publication as the number of publications is a sign of condense productivity while the number of citations is an indicator of impactful influence. Olhager J. ranks first with 7 documents while Shafer S. ranks second with 5 documents. 5 publications for Olhager J. and Shafer S. are 5 editorials which explicate the low number of citations. The paper "Manufacturing backshoring: a systematic literature review" for Stentoft J., Olhager J., Heikkilä J., Thoms L. published in 2016 earned 65 citations at the time we extracted the data. Although Holmstrm J, Kalchschmidt M. and Stentoft J. contributed to 4 papers each, they earned the highest H-index of 4. Distinctly, the top 20 authors approximately contributed to $36 \%$ of total publications.

From another perspective, Neely A. stands as the most influential scholar among the top 20 authors with 719 citations and 359.50 average citation per document. Vinelli A., Stentoft J. and Holmstrm J. ranked in the next positions with total citations of 122,121 , and 116 , respectively.

Moreover, Fig. 2 elaborates on the top 20 author's production over time where we closely notice that Olhager J. published its first paper "Internal and external suppliers in manufacturing networks-An empirical analysis" in 2008, while the bigger node implicates higher contribution that stands for 2012 editorials. Shafer S. extensively contributed to OMR in 2012 and 2018 while Holmstrm J. contributed to OMR since 2012. Notably, the year 2012 retraces a wealth of contribution from the top twenty authors. As for Stentoft J. who stands one of the most influential scholars, he started publication in 2014 and ended in 2016 with highly cited articles (bigger and darker node) which reflect his highest $\mathrm{H}$-index of 4.

Furthermore, Lotka's law is used to determine the frequency of publication by authors in any given field (Talukdar 2015) (Table 3). It predicts that minority of authors usually publish the majority of articles and that a high frequency rate is an indicator of authors' satisfaction to repeat their experience and publish with the same journal. The relative frequency distribution of author productivity is hyperbolic or follows an inverse square function, such that the minority of the authors are publishing the majority of the articles. More specifically, it states that the number of authors making " $n$ " contribution is about $1 / \mathrm{n}^{2}$ on those making one "C". The deviation of the observed function from the predicted inverse square function acts as a metric for the inequality in productivity of the field. 


\section{Top-Authors' Production over the Time}

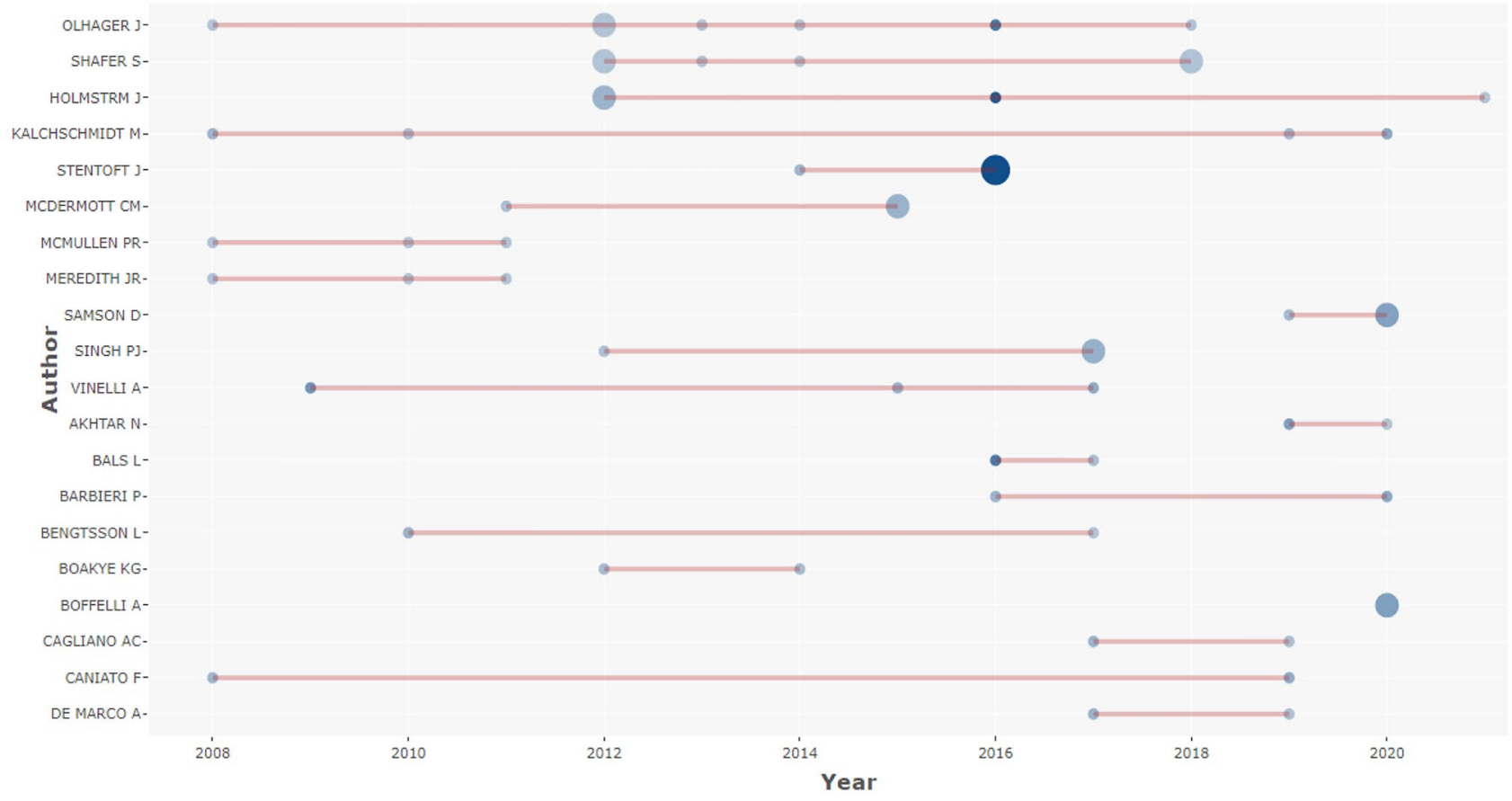

Fig. 2 The top 20 OMR authors' production over time

$88.46 \%$ of OMR active authors published 1 single paper. Based on Lotka's law, the relative proportion of the authors that have published 2 papers should have been $22.12 \%$ while $8.90 \%$ of OMR scholars have published 2 papers. Though there is negative deviation, Pao (1985) proposed a generalization to find both values ( $\mathrm{C}$ and $\mathrm{n}$ ), known as distribution of generalized inverse power or Lotka's inverse-power law.

On another scale, Table 4 highlights the top 10 universities in terms of publications. Wake Forest University, USA ranked at the top with 12 articles followed by Lund University, Sweden and The Pennsylvania State University, USA that equally contributed to 7 publications each. Out of the

Table 3 The frequency of publication by authors

\begin{tabular}{llrrr}
\hline $\begin{array}{l}\text { Docu- } \\
\text { ments } \\
\text { written }\end{array}$ & N. of Authors & $\begin{array}{l}\text { Proportion } \\
\text { of Authors }\end{array}$ & Lotka's Law & Deviation \\
\hline 1 & 368 & $88.46 \%$ & $88.46 \%$ & \\
2 & 37 & $8.90 \%$ & $22.12 \%$ & $-13.22 \%$ \\
3 & 6 & $1.44 \%$ & $9.83 \%$ & $-8.39 \%$ \\
4 & 3 & $0.72 \%$ & $5.53 \%$ & $-4.81 \%$ \\
5 & 1 & $0.24 \%$ & $3.54 \%$ & $-3.30 \%$ \\
7 & 1 & $0.24 \%$ & $1.81 \%$ & $-1.57 \%$ \\
\hline
\end{tabular}

This table shows the frequency of publications by OMR authors between 2002 and 2020 top 10 performing universities, $60 \%$ are American and $20 \%$ are Swedish. Interestingly, Cranfield School of Management, UK is ranked as top cited university with 727 (23.97\% of total citations) followed by the University of Cambridge, UK that earned 724 citations (23.87\% of total citations). The top 10 universities have total 2,308 citations $(76.10 \%$ of total citations). Out of the top 10 cited universities, $20 \%$ of the universities (UK) secured $62.86 \%$ citation while the remaining universities hold $37.13 \%$ citations. It is worth mentioning that USA stands as the leading contributor in terms of publications whereas UK is the leading in terms of citations. In their bibliometric analysis of the "International Journal of Logistics Research and Applications", Wang et al. (2019) found that Cranfield School of Management is the most productive and influential university. This finding is grounded by the fact that the latter university is playing a pivotal role in the publication field in the areas of operation management and supply chain.

On a country level, USA contributed to the highest number of publications (68) followed by Italy (20), Sweden (15) and United Kingdom (15) as showed in Table 5. The top 4 ranking countries contributed to $71.08 \%$ of total OMR publications. From the citation perspective as UK topped the list with 1,003 citations that account for $33.06 \%$ of total citations. USA secured the second place (859) with $24 \%$ of total citations while Italy earned the third position (294). UK and USA contributed to more than $61 \%$ of total citations. 
Table 4 Top 10 universities

\begin{tabular}{llllc}
\hline Organization & Country & Documents & Citations & $\begin{array}{c}\text { Citations per } \\
\text { publication }\end{array}$ \\
\hline Wake Forest University & USA & 12 & 16 & 1.33 \\
Lund University & Sweden & 7 & 70 & 10 \\
The Pennsylvania State University & USA & 7 & 177 & 25.29 \\
Aalto University & Finland & 6 & 237 & 39.5 \\
University of Melbourne & Australia & 6 & 33 & 5.5 \\
Georgia Southern University & USA & 5 & 26 & 5.2 \\
Chalmers University of Technology & Sweden & 4 & 90 & 22.5 \\
East Carolina University & USA & 4 & 70 & 17.5 \\
University of Cambridge & UK & 3 & 724 & 241.33 \\
Cranfield School of Management & UK & 2 & 727 & 363.5 \\
\hline
\end{tabular}

This table ranks the top 10 institutions affiliated in terms of publications between 2008 and 2020

In their bibliometric analysis of "The International Journal of Production Research", Wang and Sun (2019) emphasized how the journal gained prominence over time. More than 99 countries/regions contributed to shift the journal 'dependency from its top ten authors to a wider array of authors. This fact has increased the journal ability to widen its scope of research and to expand the number of its authors.

Thus, OMR should initiate new policies to attract scholars from Asian countries to amplify its productivity and magnify its diversity. More specifically the journal should coordinate with international universities to conduct conferences and roundtables with market analysts and policy makers. The editorial board can play a significant role in setting future guidelines and strategies for OMR path such as increasing the thickness of publication, widening the scope

Table 5 Top 15 countries in terms of total publications

\begin{tabular}{llll}
\hline Country & Documents & Citations & $\begin{array}{c}\text { Citation Per } \\
\text { Document }\end{array}$ \\
\hline United States & 68 & 859 & 12.63 \\
Italy & 20 & 294 & 14.7 \\
Sweden & 15 & 159 & 10.6 \\
United Kingdom & 15 & 1003 & 66.87 \\
China & 14 & 69 & 4.93 \\
Australia & 10 & 41 & 4.1 \\
Denmark & 8 & 232 & 29 \\
Finland & 8 & 215 & 26.88 \\
Canada & 7 & 136 & 19.43 \\
India & 7 & 13 & 1.86 \\
Germany & 6 & 173 & 28.83 \\
Netherlands & 5 & 118 & 23.6 \\
Pakistan & 5 & 8 & 1.6 \\
South Korea & 5 & 78 & 15.6 \\
Belgium & 4 & 42 & 10.5 \\
\hline
\end{tabular}

This table ranks the top 15 countries affiliated with OMR authors, in terms of publications between 2008 and 2020 along with suggesting formal and informal market campaign. Samson (2020) suggested hot topics to be investigated in the future such as: the disruptive effect of COVID19 , the impact of ageing population and its impact on the labor market, supply chain and OM habits, the inequality among OECD and developing countries, modern slavery, the low interest rates, industry 4.0 and digitalization effect, risk and resilience, CSR/ESG and many interesting topics. This drew attention on the effort put by editors to attract top scholars and the need to assess and study the new and disruptive changes in $\mathrm{O} / \mathrm{SCM}$ trends and in other related functional areas.

\subsection{Citation analysis}

Figure 3 shows the citation growth of the journal measured by the yearly citation and the accumulated citation indicators. The yearly citation swings from a high of 943 citations in 2008 to a low level over the last 3 -year periods where it plummeted to 30, 55, and 45 in 2018, 2019 and 2020, respectively. Notably, OMR publications were specifically influential in 2016 with 422 earned. Though the accumulated yearly citations displayed an uptrend steady growth, the last three years record the lowest number of citations as such trends have been common across journals due to the time specific nature of citations (Baker et al. 2020).

Table 6 provides an in-depth analysis of the yearly citation trend. Out the 166 total publications, 140 documents or $84.3 \%$ received at least one citation. Only 26 articles were not cited out of which there are 5 editorials and 22 articles published in 2020-2021. In the past few years, the total cites per publication (TC/TP) and total cites per cited publication (TC/TCP) were experiencing a downward trend. For example, in 2008, TC/TP was 62.9 which sharply dropped during the last three years and reached the lowest level (2 citations) in 2020. Similarly, TC/TCP depicted 67.4 in 2008 which fell to 5 in the last two years 2019-2020. Indeed, the citations of the latest 
Fig. 3 OMR citation growth between 2008 and 2020

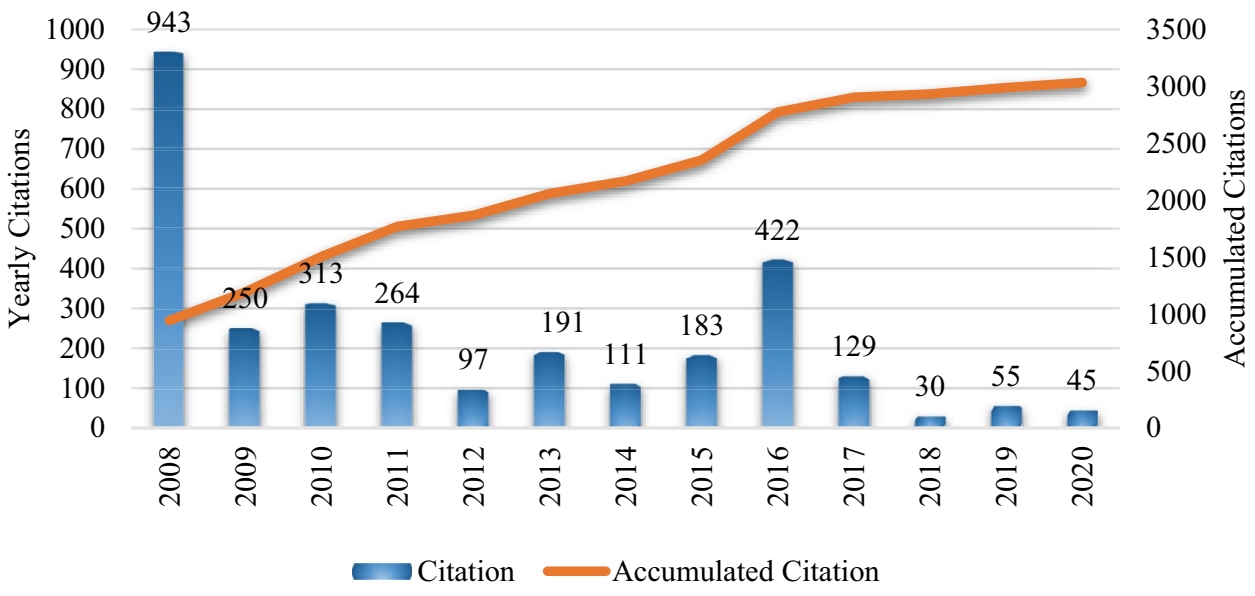

Note(s): This figure shows the yearly citations between 2008 and 2020 and the accumulated citations in red. publications need time to accrue. Moreover, it is discernable that 86 articles or $61.43 \%$ were cited only from 1 to 9 times, 47 articles $33.57 \%$ received 10-49 citations, 6 articles received 50-99 citations while only one article received more than 100 citations. Figure 4 provides a clear reflection on the trend of published articles versus cited ones. It compares the number of total publications (TP) with the number of cited publications (TCP) where at the beginning (2008-2011), both indicators co-walked at approximately the same pace which indicates the equilibrium between OMR productivity and influential impact. The gap widened in 2020 where the number of cited articles (9) shrunk to $40.9 \%$ of total published ones (22). This latter finding is very normal since citations of recent publications need time to accrue.

To investigate OMR influential publications, we extract the top 15 papers in terms of yearly citations presented in Table 7. Neely's publication in 2008 titled "Exploring the financial consequences of the servitization of manufacturing" earned the highest citations per year. The second document (Holmström et al. 2016) titled "The direct digital manufacturing (r)evolution: definition of a research agenda" achieved the 2nd rank while the yearly citation of (Pont et al. 2009) publication
Table 6 Annual number of OMR citations between 2008 and 2020

\begin{tabular}{|c|c|c|c|c|c|c|c|c|c|}
\hline \multirow[t]{2}{*}{ Year } & \multirow[t]{2}{*}{$\mathrm{TP}$} & \multirow[t]{2}{*}{ TCP } & \multirow[t]{2}{*}{$\mathrm{TC}$} & \multirow[t]{2}{*}{ TC/TP } & \multirow[t]{2}{*}{$\mathrm{TC} / \mathrm{TCP}$} & \multicolumn{4}{|c|}{ Publications with citations } \\
\hline & & & & & & $>100$ & $50-99$ & Oct-49 & 9-Jan \\
\hline 2008 & 15 & 14 & 943 & 62.9 & 67.4 & 1 & 1 & 7 & 5 \\
\hline 2009 & 8 & 7 & 250 & 31.3 & 35.7 & 0 & 2 & 4 & 1 \\
\hline 2010 & 18 & 17 & 313 & 17.4 & 18.4 & 0 & 1 & 10 & 6 \\
\hline 2011 & 16 & 16 & 264 & 16.5 & 16.5 & 0 & 0 & 10 & 6 \\
\hline 2012 & 13 & 11 & 97 & 7.5 & 8.8 & 0 & 0 & 5 & 6 \\
\hline 2013 & 10 & 9 & 191 & 19.1 & 21.2 & 0 & 2 & 3 & 4 \\
\hline 2014 & 12 & 10 & 111 & 9.3 & 11.1 & 0 & 0 & 4 & 6 \\
\hline 2015 & 10 & 10 & 183 & 18.3 & 18.3 & 0 & 0 & 1 & 9 \\
\hline 2016 & 12 & 11 & 422 & 35.2 & 38.4 & 0 & 0 & 3 & 8 \\
\hline 2017 & 11 & 10 & 129 & 11.7 & 12.9 & 0 & 0 & 0 & 10 \\
\hline 2018 & 7 & 5 & 30 & 4.3 & 6 & 0 & 0 & 0 & 5 \\
\hline 2019 & 12 & 11 & 55 & 4.6 & 5 & 0 & 0 & 0 & 11 \\
\hline 2020 & 22 & 9 & 45 & 2 & 5 & 0 & 0 & 0 & 9 \\
\hline \multirow[t]{2}{*}{ Total } & 166 & 140 & 3033 & & & 1 & 6 & 47 & 86 \\
\hline & & $84.30 \%$ & & & & $0.71 \%$ & $4.29 \%$ & $\mathbf{3 3 . 5 7 \%}$ & $61.43 \%$ \\
\hline
\end{tabular}

This table shows the annual number of OMR publications, cited publication and citations between 2008 and 2020 , where $\mathrm{TP}=$ total publications, $\mathrm{TCP}=$ total cited publications, $\mathrm{TC}=$ total citations, $\mathrm{TC} / \mathrm{TP}=$ cites per publication and $\mathrm{TC} / \mathrm{TCP}=$ cites per cited publication. The remaining columns show the number of articles with at least 100,50,10 and 1 citation(s), respectively

The numbers in bold represent the total by column. $84.30 \%$ is the percentage TCP out of TP. $0.71 \%, 4.29 \%$, $33.57 \%$ and $61.43 \%$ are percentages of publications with citations out of TCP 
Fig. 4 Gap between total publications and total cited publications between 2008 and 2020

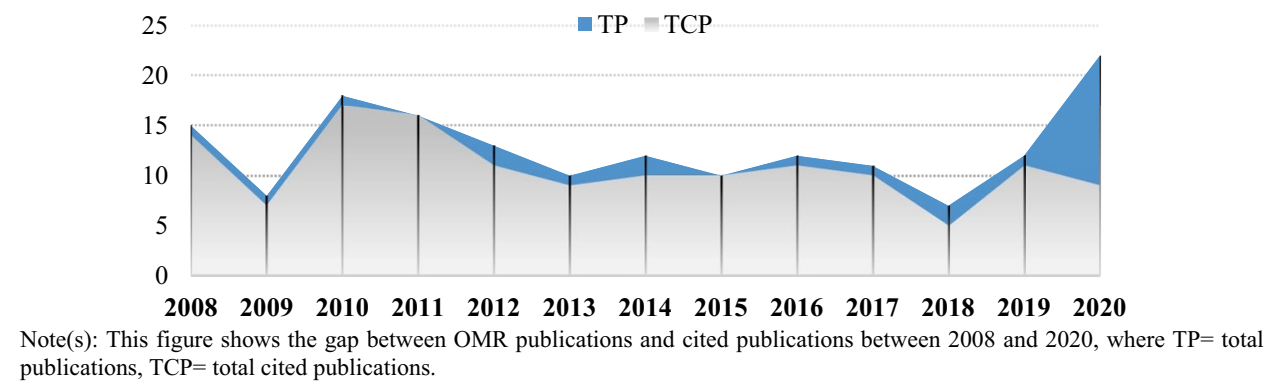

"Interrelationships among lean bundles and their effects on operational performance" earned 87 citations. In fact, there is some specific references that are most frequently cited by OMR articles. The most cited article is "Building Theories from Case Study Research Published by: Academy of Management Stable" (6 citations) published by the "The Academy of Management Review" (Eisenhardt 1989). Likewise, "Offshoring, reshoring and the manufacturing location decision" published by the "Journal of Supply Chain Management" (Ellram 2013) was also cited 6 times in OMR.

Table 8 show most frequently cited journals by OMR articles. The most cited journal is the Journal of Operations Management (Q1 and ABDC rating of A*) from which 560 articles were cited by OMR documents. Other impactful journals are the International Journal of Production Economics and The International Journal of Operations \&
Production Management from which 280 and 224 articles were respectively cited by OMR authors. This fact pinpoints the wealth of resources, and the high-quality journals OMR authors are relying on.

\subsection{Network analysis}

The network analysis is extracted from VOSviewer software. It aims at developing the connectivity between keywords based on their occurrences. A total of 576 author's keywords appears in OMR 166 documents with an average of 3.47 per document. Figure 5 shows that keywords are classified into three clusters. The red cluster represents the impact of operation strategy and the purchasing on the sustainability and firm performance, and it is investigated through empirical studies and surveys. The second cluster in the blue one which discusses the supply chain management

Table 7 The 15 most cited OMR articles by year between 2008 and 2020

\begin{tabular}{|c|c|c|c|c|}
\hline Paper & Title & Year & Total Citations & TC per Year \\
\hline (Neely 2008) & Exploring the financial consequences of the servitization of manufacturing & 2008 & 716 & 716 \\
\hline (Holmström et al. 2016) & The direct digital manufacturing (r)evolution: definition of a research agenda & 2016 & 92 & 92 \\
\hline (Pont et al. 2009) & $\begin{array}{l}\text { Interrelationships among lean bundles and their effects on operational perfor- } \\
\text { mance }\end{array}$ & 2009 & 87 & 87 \\
\hline (Langabeer et al. 2009) & $\begin{array}{l}\text { Implementation of Lean and Six Sigma quality initiatives in hospitals: A goal } \\
\text { theoretic perspective }\end{array}$ & 2009 & 73 & 73 \\
\hline (Stentoft et al. 2016) & Manufacturing backshoring: a systematic literature review & 2016 & 65 & 65 \\
\hline (Bals et al. 2016) & $\begin{array}{l}\text { Exploring the reshoring and insourcing decision-making process: toward an } \\
\text { agenda for future research }\end{array}$ & 2016 & 64 & 64 \\
\hline (Rolland et al. 2010) & Decision support for disaster management & 2010 & 63 & 63 \\
\hline (Choi and Hwang 2015) & $\begin{array}{l}\text { The impact of green supply chain management practices on firm perfor- } \\
\text { mance: the role of collaborative capability }\end{array}$ & 2015 & 56 & 56 \\
\hline (Kuhn and Sternbeck 2013) & Integrative retail logistics: An exploratory study & 2013 & 55 & 55 \\
\hline (Guide Jr. et al. 2008) & The optimal disposition decision for product returns & 2008 & 51 & 51 \\
\hline (Kim 2013) & Relationship between supply chain integration and performance & 2013 & 51 & 51 \\
\hline (Asif et al. 2010) & $\begin{array}{l}\text { Integration of management systems: A methodology for operational excel- } \\
\text { lence and strategic flexibility }\end{array}$ & 2010 & 45 & 45 \\
\hline (Robinson and Hsieh 2016) & Reshoring: a strategic renewal of luxury clothing supply chains & 2016 & 42 & 42 \\
\hline (Ashby 2016) & From global to local: reshoring for sustainability & 2016 & 42 & 42 \\
\hline (Davis et al. 2011) & $\begin{array}{l}\text { Guest editorial: How technology is changing the design and delivery of } \\
\text { services }\end{array}$ & 2011 & 41 & 41 \\
\hline
\end{tabular}

This table lists the 15 most cited OMR articles between 2008 and 2020 with the published year and the number of citations received 
Table 8 Top cited journals

\begin{tabular}{|c|c|c|c|c|c|c|}
\hline \multicolumn{7}{|l|}{ Most cited sources } \\
\hline Sources & Articles & CiteScore & SNIP & SJR & Quartile & ABDC \\
\hline Journal of Operations Management & 560 & 11.4 & 3.014 & 3.957 & 1 & $A^{*}$ \\
\hline International Journal of Production Economics & 280 & 10.5 & 2.714 & 2.379 & 1 & A \\
\hline $\begin{array}{l}\text { International Journal of Operations \& Produc- } \\
\text { tion Management }\end{array}$ & 224 & 9.1 & 2.442 & 2.187 & 1 & A \\
\hline International Journal of Production Research & 157 & 7.6 & 2.075 & 1.776 & 1 & A \\
\hline Operations Management Research & 155 & 8.4 & 1.66 & 1.231 & 1 & $\mathrm{C}$ \\
\hline European Journal of Operational Research & 144 & 8.5 & 2.875 & 2.364 & 1 & $A^{*}$ \\
\hline Management Science & 144 & 7 & 3.254 & 5.439 & 1 & $A^{*}$ \\
\hline Journal of Supply Chain Management & 119 & 13.4 & 2.887 & 3.983 & 1 & A \\
\hline Journal of Purchasing \& Supply Management & 112 & 6.4 & 1.885 & 1.473 & 1 & A \\
\hline Production and Operations Management & 109 & 4.7 & 1.95 & 2.843 & 1 & $\mathrm{~A}^{*}$ \\
\hline Strategic Management Journal & 102 & 11.5 & 3.624 & 8.43 & 1 & $\mathrm{~A}^{*}$ \\
\hline Journal of Cleaner Production & 93 & 10.9 & 2.394 & 1.886 & 1 & A \\
\hline Decision Sciences & 92 & 3.9 & 1.419 & 1.329 & 1 & $\mathrm{~A}^{*}$ \\
\hline Harvard Business Review & 91 & 1.9 & 0 & 0.461 & 2 & A \\
\hline Journal of Marketing & 91 & 15.1 & 5.154 & 8.626 & 1 & $\mathrm{~A}^{*}$ \\
\hline
\end{tabular}

This table lists the 15 most cited journals by OMR's articles between 2008 and 2020, with their impacts. Cite score measures the average citation per published document; SNIP (Source Normalized Impact Per Paper) measures citations weighted by subject field; SJR (SCImago Journal Rank) measures citations weighted by prestige; Quartile is according to SCImago; ABDC provides the ranking based on Australian Business Deans Council

ABDC ranking has four categories: $\mathrm{A}^{*}$ (highest), A, B, C (lowest)

in the reshoring, offshoring and backshoring and is mainly investigated in case studies and surveys. Finally, the green cluster tackles the supply chain and performance with regards to the six sigma, lean, and city logistics. It is mainly investigated in the healthcare and hospitals. To capture deeper insights, we employ VOSviewer to visualize the time span for each topic, the lighter nodes indicate more recent topics. Figure 6 clearly demonstrates that the oldest topics are emphasized in the areas of six sigma, purchasing, quality, and performance. In 2013-2016, topics such as "the manufacturing supply chain management and operational performance" gained popularity. While the most recent topics focus on the reshoring, offshoring, operations strategies, city logistics, and sustainability. OMR structural and temporal themes serves to highlight persistent research themes, cold and hot ones. "Supply chain", "Operations management", "Operational performance", "Efficiency" and "Strategy" are persistent themes. The journal calls for the emphasis of reshoring and relocating as many multi- and transnational companies are rethinking about the supply chain system in disruptive times. Many analyses are worth studying such as top management resilience and agility in times of constraints and major events.

Likewise, the countries co-authorship was developed. Figure 7 presents that USA is the journal lead contributor within the red network that includes Sweden, Finland, Canada, and India. While UK is at the center of the green network that includes China, Pakistan, Oman, and
Singapore. Lastly, Italy is at the center of the blue network, which highlights the influential collaboration with other countries such as Australia, Spain, Denmark, and Germany. The country collaboration network conveys a clear message on the necessity to account for other countries. Figure 8 presents countries' network by seniority. The oldest network stands as Hong Kong, Switzerland, Taiwan, and Japan while the recent collaborative network includes India, Pakistan, Ghana, and United Arab Emirates. Nowadays, there is a surge in research productivity coming from these latter countries and OMR should strategize the next moves to capture wider areas that might positively curb its publication and lead to improve its benchmarking on the ABDC list.

\section{Content analysis}

This section offers a general overview for the nature of topics discussed in OMR over its life. It includes keywords analysis, topics trend, conceptual structure, and cluster discussion.

\subsection{Keywords analysis/topics trend}

$\mathrm{R}$ studio is used to visualize the words cloud, based on the authors' keywords in OMR published documents. The most frequent keywords (KW) are supply chain, reshoring, 


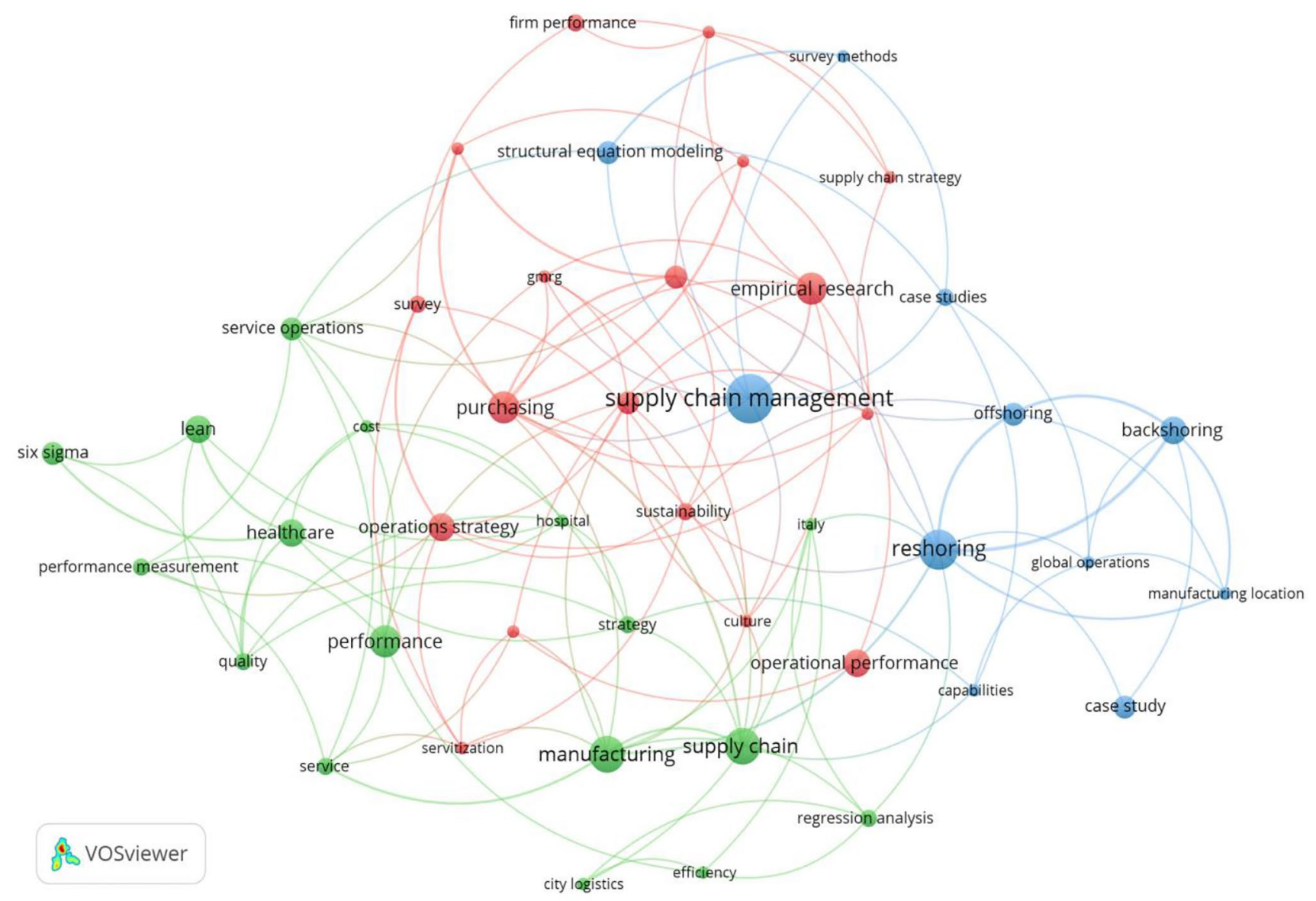

Fig. 5 Author keywords network of OMR articles

manufacturing, and empirical studies (Fig. 9). The yearly keywords trends retrace the themes path over the period 2008-2020. While the hottest years for some specific themes are very apparent, the years of loss for some other topics are also depicted. For instance, the research in "Reshoring" theme soared between 2015-2017 which matches the claim of Samson in his 2020 editorial note to revisit the reshoring topic and address the ensuing impact of COVID-19 disruption.

\subsection{Conceptual structure and clusters overview}

We advanced our analysis and use $\mathrm{R}$ studio to reveal the main OMR clusters through conceptual structure. Figure $10 \mathrm{seg}-$ regates the topics into three main groups: "Manufacturing and supply chain performance" (pink), "Six sigma and lean management" (blue) and "Reshoring, backshoring and offshoring" (green).

\subsubsection{Cluster 1: manufacturing and supply chain performance}

The first cluster is named "Manufacturing and Supply Chain Performance". It consists of 101 OMR publications accredited with 2,108 citations. It ranks first in terms of publications and citations (Fig. 11). As shown in the figure above, the cluster is a conglomerate of three sub-clusters that present views on performance, manufacturing, supply chain and operations management. Therefore, the topics represented in the cluster tend to focus on central models such as: assessing performance, managing supply chain, and manufacturing and operations management practices. Neely (2008) article titled "Exploring the financial consequences of the servitization of manufacturing" is the most cited (719) with an average cites per year (359.50). The author seeks to fill the gap in the literature by presenting empirical evidence on the range and extent of servitization based on database of 10,028 firms incorporated in 25 different countries. Holmström et al. (2016) article ranks second (92 citations). Their work offers a wealth of opportunities for product and process innovation and is often touted to 'revolutionize' today's manufacturing operations and its associated supply chains structures. As such, we conclude that direct digital manufacturing will increasingly challenge operations management researchers to question established practices such as scheduling, batch sizing and inventory management in low-volume, high-variety 


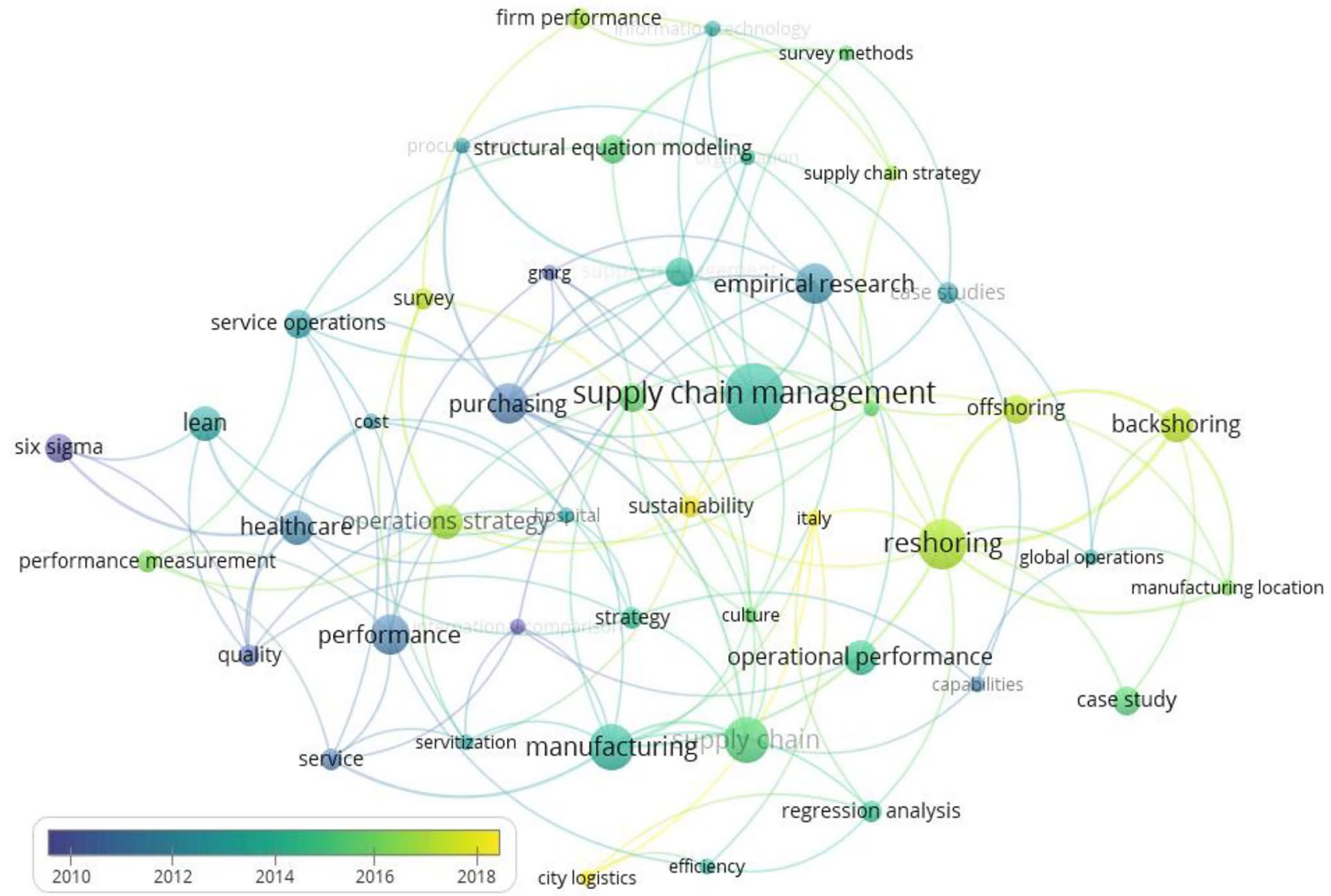

Fig. 6 Author keyword timeline of OMR article

contexts. Furthermore, an increasing adoption of direct digital manufacturing will drive structural shifts in the supply chain that are not yet well understood. We summarize these challenges by defining the research agenda at factory, supply chain, and operations strategy levels. Rolland et al. (2010) article occupies the third slot with 63 citations in the cluster. The study proposes a decisionsupport system for disaster response and recovery using hybrid meta-heuristics. Decision-support systems used in disaster management must cope with the complexity and uncertainty involved with the scheduling and assignment of differentially skilled personnel and assets to specific tasks. Other important works in the cluster include Choi \& Hwang (2015) article, cited 56 times, and Kuhn and Sternbeck (2013) article, cited 55 times.

\subsubsection{Cluster 2: six sigma and lean management}

The second cluster is under the "Six Sigma and Lean Management". It consists of 42 OMR articles published between 2008 and 2020 (cited 617 times) (Fig. 12). It ranks second in the number of publications and citations. Major covered topics are process improvement, operations strategy, six sigma hospital, lean management in healthcare, supply chain management, and service quality. Chakravorty (2009) article is the most influential in the cluster (87 citations). His paper is titled "Six Sigma failures: An escalation model" in which he describes a Six Sigma failure in an electrical components company. The research contributes to both practice and theory as it provides a new direction to academic research and has the potential to impact the theory of Six Sigma. It practically uncovers important factors for the successful implementation of the Six Sigma and it theoretically reflects on its definition by pinpointing its commonalities and divergences. Langabeer et al. (2009) article is the second most influential work in the cluster ( 73 citations). This article is a cross-sectional analysis that relies on mixed research methods (survey questionnaire and semi-structured interviews). It aims to investigate the implementation of two quality-improvement methods (Lean and Six Sigma) in the context of hospitals. The research concludes to important findings about the impact of such methods on goal and value attainments in the healthcare industry. Robinson and Hsieh (2016) article is the third highly cited work in the cluster (42 citations). The study contributes to the emerging literature on reshoring by taking a value-driven enquiry 


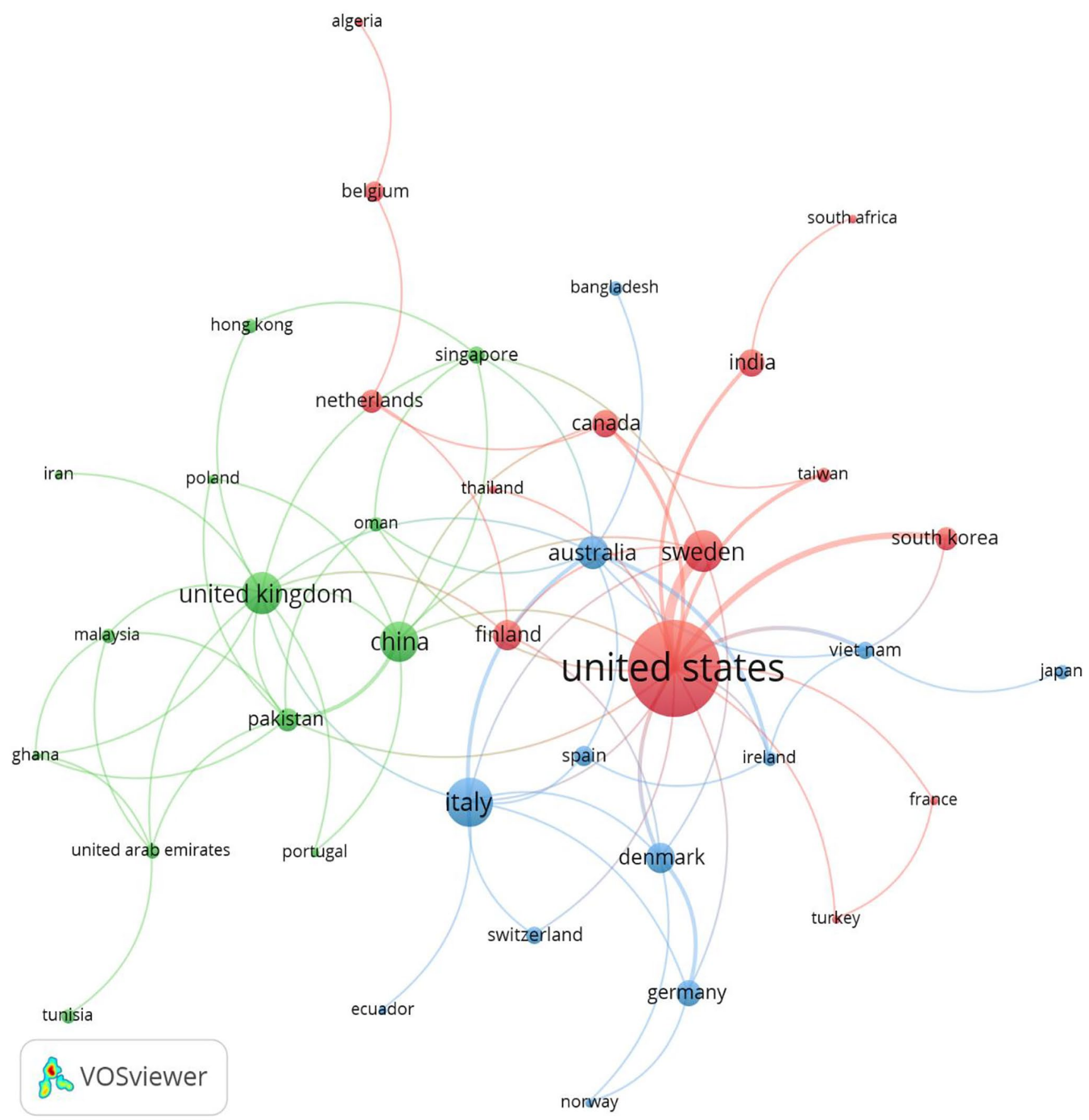

Fig. 7 Network of countries affiliated with OMR

into the renewal of supply chain strategy. It enhances the understanding of reshoring as a changing business model. An iconic British high-end clothing brand, Burberry, is the chosen case study to explore its recent move towards reshoring while accounting for different metrics such as: change in leadership, business model and evolving supply chain strategy from 1997 to early 2016. These findings suggest that the renewal of supply chain strategy through reshoring and increasing control can enhance the firm value and competitiveness. The other influential works subsumed in the cluster include Lifvergren et al. (2010) article and Zeng et al. (2013) which are cited 38 times each, respectively. The first study presents key applications not earlier described in prior Six Sigma healthcare fields. However, the second paper proposes a conceptual framework to study the relationships among three dimensions of supply chain quality management (SCQM) - in-house quality management practices (internal QM), quality interaction with suppliers 


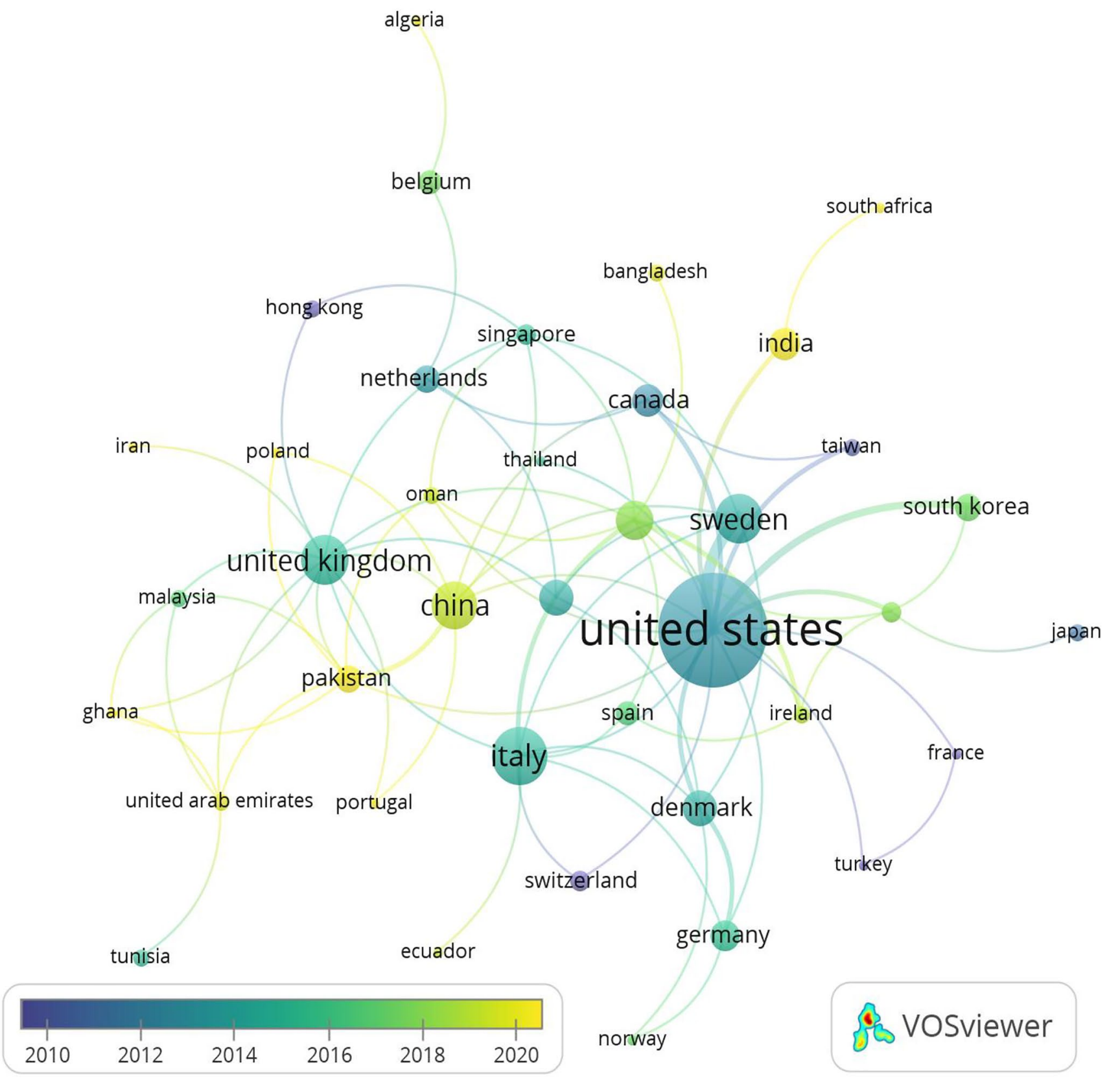

Fig. 8 Network of countries affiliated to OMR per year

on the upstream side of supply chain (upstream QM), and quality interaction with customers on the downstream side of supply chain (downstream QM) - and their impact on two metrics of quality performance (conformance quality and customer satisfaction).

\subsubsection{Cluster 3: reshoring, backshoring and offshoring}

The last cluster is called "Reshoring, Backshoring, and Offshoring". This cluster consists of 23 OMR articles cited 308 times, thus ranking third in terms of both publications and citations (Fig. 13). Key topics deliberated in the cluster include reshoring, backshoring, location decisions, and captive offshoring. Stentoft et al. (2016) article is the most cited work (65 times) where they conduct a systematic review of all prior research related to backshoring of manufacturing and conclude to provide a research agenda for further research. Bals et al. (2016) essay is the next most influential work (cited 64 times). It aims to clarify the decision-making processes related to two distinct phenomena of reshoring and insourcing and present a conceptual framework of all theoretically possible reshoring and insourcing decisions. Ashby (2016) article, cited 42 times, is the third most influential work in the cluster. He attempts to explore the effect of 

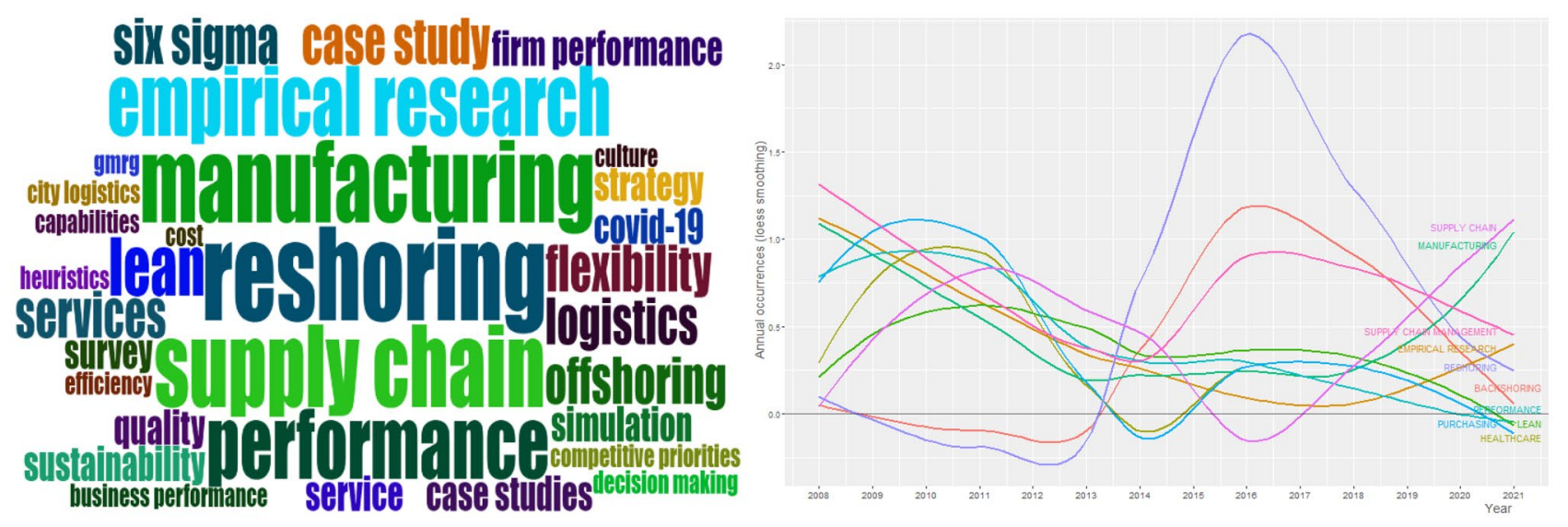

Fig. 9 OMR Keywords cloud

sustainability on reshoring strategy by studying the case of a UK-based clothing SME. Other important works in the cluster include Joubioux and Vanpoucke (2016) article and Zhai et al. (2016) article, cited 31 times each, respectively.

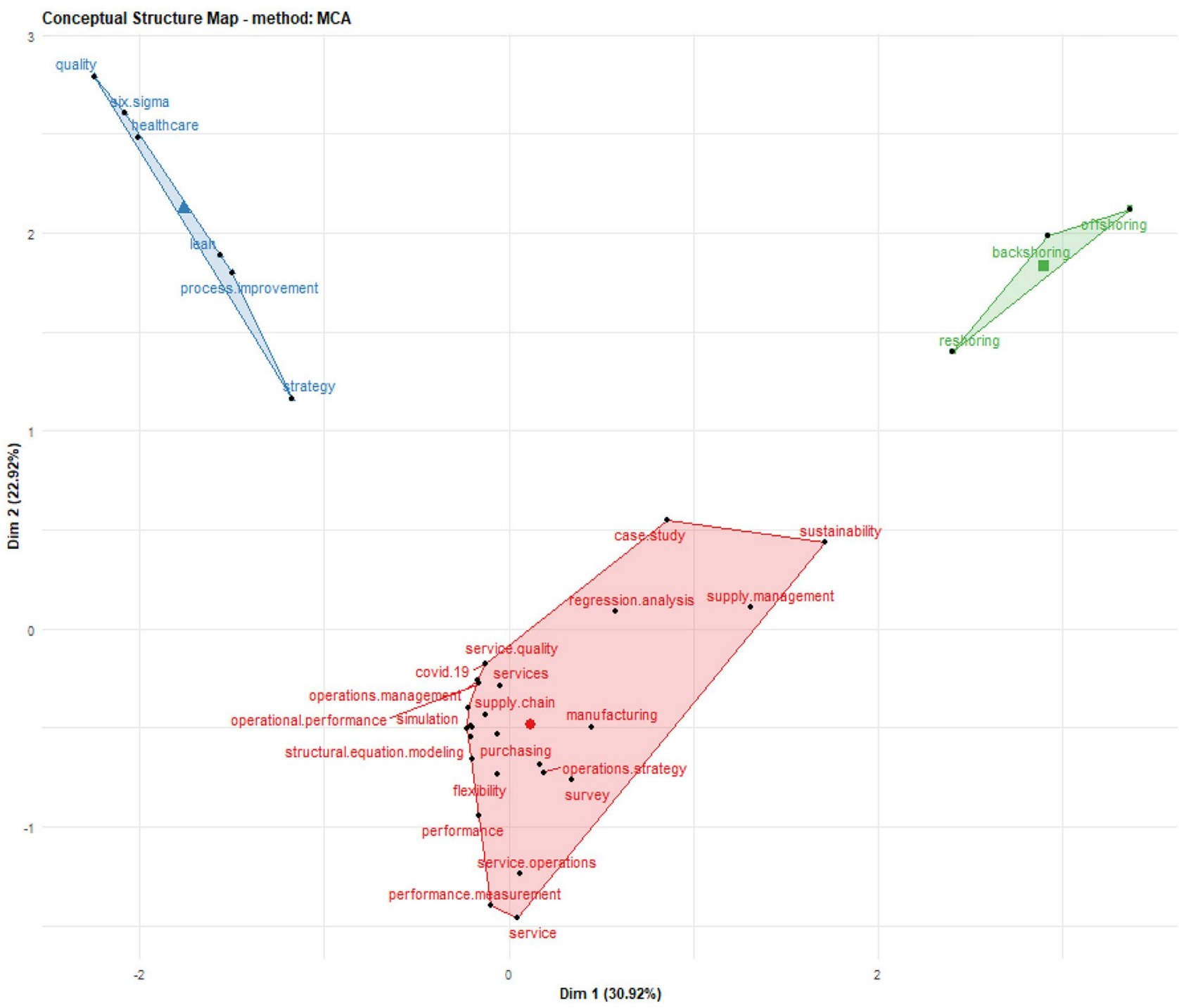

Fig. 10 Conceptual Structure Map of OMR major themes 


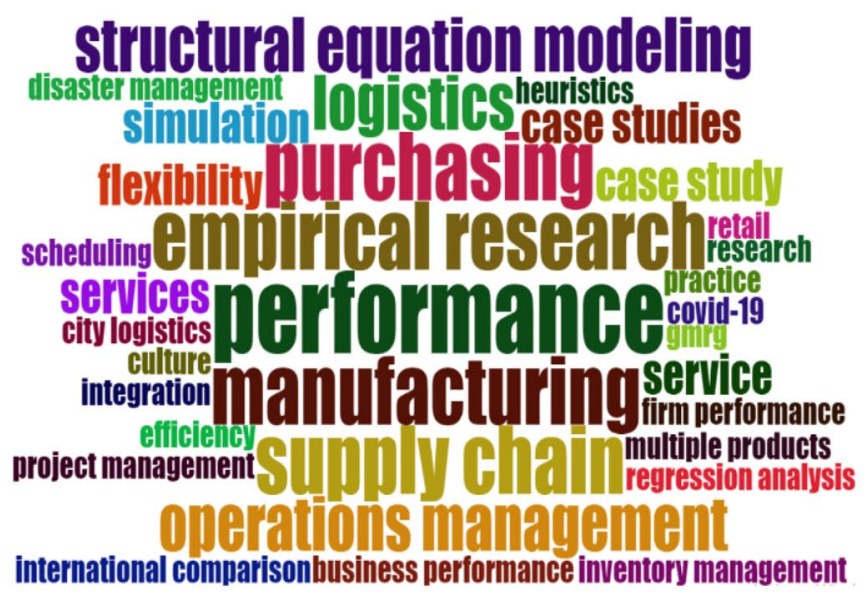

Fig. 11 Cluster 1: Keyword cloud and yearly growth

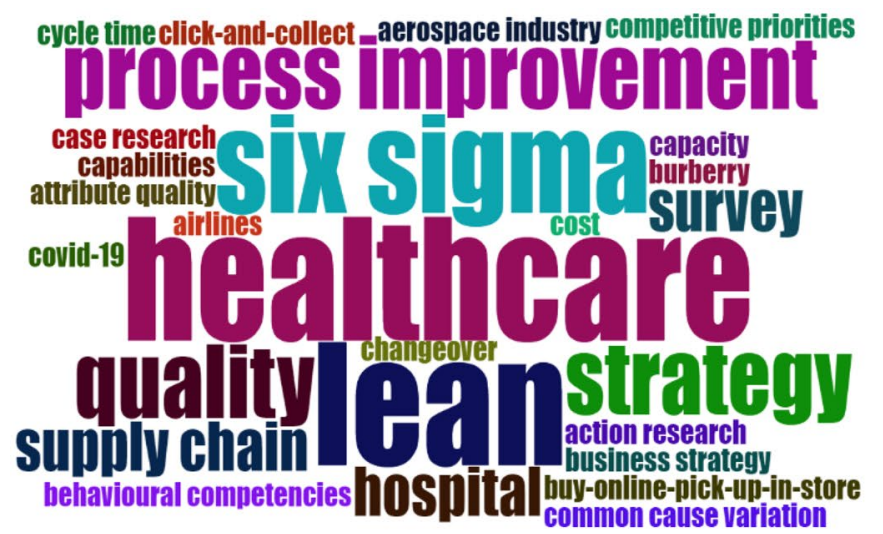

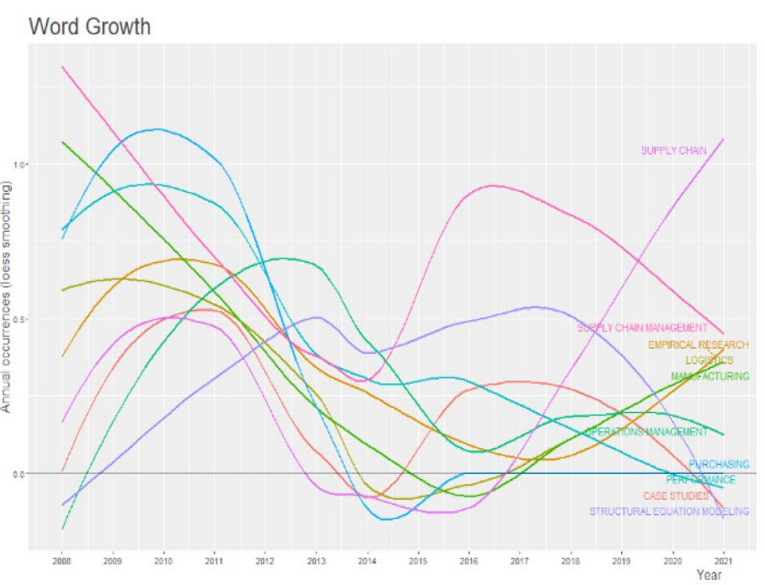

Fig. 12 Cluster 2: Keyword cloud and yearly growth
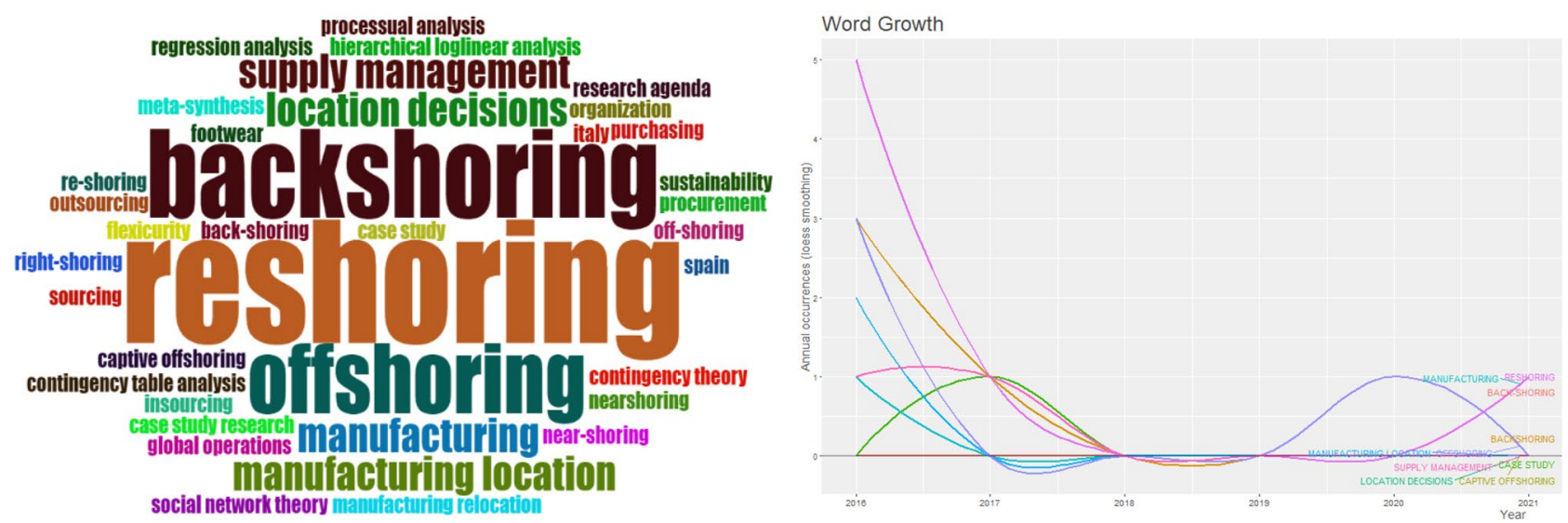

Fig. 13 Cluster 3: Keyword cloud and yearly growth

\section{Future agenda}

This section addresses themes publication gap. Emergent topics such as the implication and consequences of the fourth industrial revolution and the influences of COVID 19 on the business

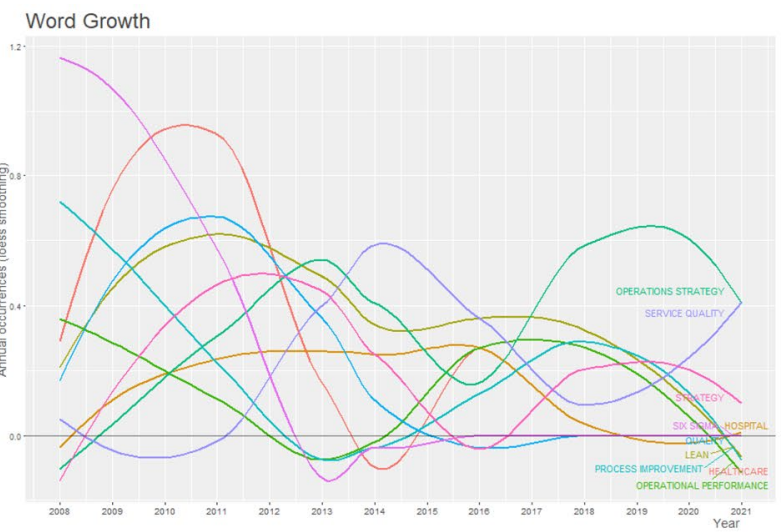


Table 9 OMR articles related to Industry 4.0

\begin{tabular}{|c|c|c|c|}
\hline Authors & Title & Year & Cited \\
\hline Turunen T.T., Toivonen M & Organizing customer-oriented service business in manufacturing & 2011 & 33 \\
\hline Gallmann F., Belvedere V & $\begin{array}{l}\text { Linking service level, inventory management and warehousing practices: A } \\
\text { case-based managerial analysis }\end{array}$ & 2011 & 11 \\
\hline Mirzabeiki V., Holmström J., Sjöholm P & Aligning organisational interests in designing rail-wagon tracking & 2012 & 4 \\
\hline Holmström J., Holweg M., Khajavi S.H., Partanen J & The direct digital manufacturing (r)evolution: definition of a research agenda & 2016 & 93 \\
\hline Cao Q., Schniederjans D.G., Schniederjans M & Establishing the use of cloud computing in supply chain management & 2017 & 16 \\
\hline Ajmera P., Jain V & $\begin{array}{l}\text { Modelling the barriers of Health } 4.0-\text { the fourth healthcare industrial revolu- } \\
\text { tion in India by TISM }\end{array}$ & 2019 & 6 \\
\hline Nabi H.Z., Aized T & $\begin{array}{l}\text { Performance evaluation of a carousel configured multiple products flexible } \\
\text { manufacturing system using Petri net }\end{array}$ & 2020 & 2 \\
\hline Yadav S., Luthra S., Garg D & $\begin{array}{l}\text { Internet of things (IoT) based coordination system in Agri-food supply chain: } \\
\text { development of an efficient framework using DEMATEL-ISM }\end{array}$ & 2020 & 1 \\
\hline Mukherjee A.A., Singh R.K., Mishra R., Bag S & $\begin{array}{l}\text { Application of blockchain technology for sustainability development in } \\
\text { agricultural supply chain: justification framework }\end{array}$ & 2021 & \\
\hline Dharmawardane C., Sillanpää V., Holmström J & $\begin{array}{l}\text { High-frequency forecasting for grocery point-of-sales: intervention in prac- } \\
\text { tice and theoretical implications for operational design }\end{array}$ & 2021 & \\
\hline
\end{tabular}

Table 10 OMR articles related to COVID 19

\begin{tabular}{|c|c|c|c|}
\hline Authors & Title & Year & Cited by \\
\hline Yu Z., Razzaq A., Rehman A., Shah A., Jameel K., Mor R.S & $\begin{array}{l}\text { Disruption in global supply chain and socio-economic shocks: } \\
\text { a lesson from COVID-19 for sustainable production and } \\
\text { consumption }\end{array}$ & 2021 & \\
\hline Qin X., Godil D.I., Khan M.K., Sarwat S., Alam S., Janjua L & $\begin{array}{l}\text { Investigating the effects of COVID-19 and public health expend- } \\
\text { iture on global supply chain operations: an empirical study }\end{array}$ & 2021 & 1 \\
\hline Wen Z., Liao H & $\begin{array}{l}\text { Capturing attitudinal characteristics of decision-makers in group } \\
\text { decision making: application to select policy recommendations } \\
\text { to enhance supply chain resilience under COVID-19 outbreak }\end{array}$ & 2021 & \\
\hline Mahmoudi A., Javed S.A., Mardani A & $\begin{array}{l}\text { Gresilient supplier selection through Fuzzy Ordinal Priority } \\
\text { Approach: decision-making in post-COVID era }\end{array}$ & 2021 & \\
\hline $\begin{array}{l}\text { Barbieri P., Boffelli A., Elia S., Fratocchi L., Kalchschmidt } \\
\text { M., Samson D }\end{array}$ & What can we learn about reshoring after Covid-19? & 2020 & 12 \\
\hline Chowdhury M.T., Sarkar A., Paul S.K., Moktadir M.A & $\begin{array}{l}\text { A case study on strategies to deal with the impacts of COVID-19 } \\
\text { pandemic in the food and beverage industry }\end{array}$ & 2020 & 10 \\
\hline Yadav S., Luthra S., Garg D & $\begin{array}{l}\text { Internet of things (IoT) based coordination system in Agri-food } \\
\text { supply chain: development of an efficient framework using } \\
\text { DEMATEL-ISM }\end{array}$ & 2020 & 2 \\
\hline Oeser G., Romano P & $\begin{array}{l}\text { Exploring risk pooling in hospitals to reduce demand and lead } \\
\text { time uncertainty }\end{array}$ & 2020 & \\
\hline
\end{tabular}

significant attention from scholars, practitioners, policymakers, and governments. Industry 4.0 advent has fostered several emerging technologies such as: Machine Learning (ML), Data Sciences, Cloud Computing, Robotic Systems, Artificial Intelligence (AI), and Internet of Things (IoT) (Dalenogare et al. 2018). These novel technologies prompt dramatic disruptions in the manufacturing and business practices: management style, business environment, marketing, labor market, competition environment, and customer behavior (Maresova et al. 2018; Moll and Yigitbasioglu 2019). Accordingly, several studies are carried to explore and investigate the potential opportunities and challenges in different knowledge domains in the fourth industrial revolution era such as: Economy (Goryachikh et al. 2020); Sustainability and Accounting (Meseguer-Sánchez et al. 2021); Industrial performance (Dalenogare et al. 2018); Business practices (Maresova et al. 2018) and Industrial practices (Zhang and Chen 2020). 
Nevertheless, OMR traces shy attempts in this knowledge area. We carry a query ${ }^{1}$ on the industrial revolution terminologies from the Scopus database and limit our search to the OMR documents. The query concludes to 10 documents as shown in Table 9.

We also carried a query to depict the contribution in the COVID 19 knowledge area. ${ }^{2}$ The query revealed eight papers distributed equally over 2020 and 2021 . Novel coronavirus COVID-19 carried serious consequences to several aspects including human being and industries. The Oxford business group examined the consequences of COVID-19 on the supply chain industry. The outcomes documented that the sector was severely affected due to a drop in population mobility and quarantine policy which led to a sharp change in consumers behavior. Also, countries lockdown and airports and borders' closure placed a significant strain on the global supply chains (Elnahass et al. 2021; Shen et al. 2020). Interestingly, Yadav et al. (2020) examined the rule of Internet of Things (IoT) in overriding disasters such as COVID 19 (Table 10). They found that (IoT) enhances the efficiency of information sharing by supporting top management and leveraging their ability to develop accurate and timely decisions.

We thus recommend OMR to encourage more publications relevant to the fourth industrial revolution and to the sequels of COVID-19.

\section{Conclusion}

This study provides an in-depth analysis of OMR's publications, annual citation structure and trend, and its intellectual evolution over the period 2008-2020. We have conducted a bibliometric analysis where we drew on OMR influential

\footnotetext{
${ }^{1}$ Query: ((SOURCE-ID $\left.(15,700,154,705)\right)$ AND TITLE-ABSKEY("emerging information technolog*" OR "emerging technolog*" OR "Forth industr*" OR "industr* 4.0" OR "intelligenc*" OR "intelligent" OR "industry 4.0" OR "information system*" OR "machine learnin*" OR "deep learning*" OR "deep mining*" OR "fuzzy" OR "Fuzzy logic" OR "Big*data" OR "bigdata" OR "data*mining" OR "block*chain" OR "Blockchain" OR "Distributed Ledger Technology" OR "collaborative databases" OR "Natural Language Processing" OR "cognitive technologies" OR "augmented reality" OR "automat*" OR "Smart contracts" OR "busines* intelligen*" OR "cloud" OR "cloud*computing" OR "cognitive*" OR "Disruptive technology" OR "decision*support*" OR "digita*" OR "disruptive*technolog*" OR "electronic* accounting*" OR "electronic data interchang*" OR "EDI" OR "expert system*" OR "grid comput*" OR "image process*" OR "image recognit*" OR "industrial revolution*" OR "integrated application*" OR "integrated system*" OR "internet of things" OR "IOT" OR "neural network*" OR "neuro" OR "quantum comput*" OR "robotic*" OR "robots" OR "smart contract*" OR "text mining*")).

2 Query: ((SOURCE-ID $(15,700,154,705))$ AND TITLE-ABS-KEY ( "epidemic" OR "covid-19" OR "coronavirus" OR "corona-virus" OR "corona virus" OR "pandemic" OR "covid19")).
}

impact, ongoing changes, future direction, and innovative methodologies. We were motivated by the fact that there is lack of discussion on hot topics and future directions based on keywords analysis.

We have used VOSviewer, R studio, and Microsoft Excel to derive insightful metrics to benchmark OMR relatively to peer journal in the same field and analyze its performance and temporal development. VOSviewer was used to carry out the mapping analysis, bibliographic coupling, keyword co-occurrences analysis, and co-authorship while $\mathrm{R}$ studio was applied to analyze the conceptual structure, productivity, most influential scientific actors, Lotka's law, and topics trend.

Over the years, OMR published 166 articles Out of which, 140 documents or $84.3 \%$ received at least one citation. OMR has an H-index of 28 and earned 3,033 citations over 13 years with 18.27 as average citations per document. The journal achieved a steady productivity growth (3.24\%) over its lifespan.

Olhager J. was the most productive authors with 7 documents while Kalchschmidt M. and Stentoft J. were the most influential authors with an $\mathrm{H}$-index of 4 and total citations of 116 and 121, respectively. Vinelli A. earned the highest citation per publication (40.67).

Cranfield School of Management, UK was ranked as top cited university with 727 (23.97\% of total citations). The top 10 universities had a total 2,308 citations $(76.10 \%$ of total citations). Out of the top 10 cited universities, $20 \%$ of the universities (UK) secured $62.86 \%$ citation while the remaining universities hold $37.13 \%$ citations.

On a country level, USA contributed to the highest number of publications (68) followed by Italy (20), Sweden (15) and United Kingdom (15). The top 4 ranking countries contributed to $71.08 \%$ of total OMR publications. From the citation perspective, UK topped the list with 1,003 citations that account for $33.06 \%$ of total citations. USA secured the second place (859) with $24 \%$ of total citations while Italy earned the third position (294). UK and USA contributed to more than $61 \%$ of total citations.

Bibliographic coupling of articles reveals three major thematic clusters: Manufacturing and supply chain performance, reshoring, offshoring and backshoring and the six sigma and lean management. OMR achieved excellence and remarkably positioned itself in the academic and scientific world. It constantly attracted prolific researchers and kept on disseminating knowledge and enlightening researcher to explore the vast field of contemporary management. In the end, we again relied on bibliometric techniques and prepared two queries to investigate two hot topics that are: Industry 4.0 and COVID-19. In addition, the inclusion of risk metric, the practicality to include preset operational buffers and the implication of top- management resilience and agility in pandemic and extreme events would constitute a main focal area for future research. 
To better benchmark OMR, we concluded to the below remarks where OMR is invited to:

- Revisit its scope as a means to more include related functional areas.

- Continue to adhere to rigorous scholarly peer reviewing process.

- Increase its publication thickness while maintaining its inherent quality of research.

- Intensify its formal and informal marketing campaign.

- Encourage scholars and countries collaborations.

- Cooperate with government policymakers, market analysts, and researchers to foster the practical emphasis of existing management theories that should be amalgamated to account for the recent disruptive events.

- Foster forum discussions on the journal platform.

- Strategize the next moves to capture wider areas that might positively curb its publication and lead to improve its benchmarking on the ABDC list.

Authors' contributions All authors have equally contributed to this article.

Funding There was no funding for this research.

Availability of data and material All data are included in the article.

\section{Declarations}

Consent for publication We state that this article is not under consideration at any other journal and if it gets accepted, we fully consent in publish in in Operations Management Research (OMR)—Springer.

Conflicts of interest There is no any kind of conflict and competing interests.

\section{References}

Ashby A (2016) From global to local: reshoring for sustainability. Oper Manag Res 9(3-4):75-88. https://doi.org/10.1007/ s12063-016-0117-9

Asif M, Fisscher OAM, de Bruijn EJ, Pagell M (2010) Integration of management systems: A methodology for operational excellence and strategic flexibility. Oper Manag Res 3(3-4):146-160. https:// doi.org/10.1007/s12063-010-0037-z

Baker HK, Kumar S, Pandey N (2021) Thirty years of the Global Finance Journal: A bibliometric analysis. Glob Financ J 47. https://doi.org/10.1016/j.gfj.2019.100492

Baker HK, Kumar S, Pattnaik D (2020) Research constituents, intellectual structure, and collaboration pattern in the Journal of Forecasting: A Bibliometric Analysis. J Forecast. https://doi.org/10.1002/for.2731

Bals L, Kirchoff JF, Foerstl K (2016) Exploring the reshoring and insourcing decision making process: toward an agenda for future research. Oper Manag Res 9(3-4):102-116. https://doi.org/10. 1007/s12063-016-0113-0
Barber RW, Mancall JC (1978) The application of bibliometric techniques to the analysis of materials for young adults. Collect Manag 2(3):229-245. https://doi.org/10.1080/J105v02n03_05

Boardman PC (2008) Beyond the stars: The impact of affiliation with university biotechnology centers on the industrial involvement of university scientists. Technovation 28(5):291-297. https://doi.org/ 10.1016/j.technovation.2007.06.001

Bookstein A (1979) Explanations of the bibliometric laws. Collect Manag 3(2-3):151-162. https://doi.org/10.1080/J105v03n02_04

Buffa ES (1980) Research in operations management. J Oper Manag 1(1): $1-7$

Caputo A, Marzi G, Maley J, Silic M (2019) Ten years of conflict management research 2007-2017: An update on themes, concepts and relationships. Int J Confl Manag 30(1):87-110. https://doi.org/10. 1108/IJCMA-06-2018-0078

Chakravorty SS (2009) Six Sigma failures: An escalation model. Oper Manag Res 2(1):44-55. https://doi.org/10.1007/ s12063-009-0020-8

Choi D, Hwang T (2015) The impact of green supply chain management practices on firm performance: the role of collaborative capability. Oper Manag Res 8(3-4):69-83. https://doi.org/10. 1007/s12063-015-0100-x

Chygryn O, Lyulyov O, Pimonenko T, Mlaabdal S (2020) Efficiency of oil-production: The role of institutional factors. Engineering Management in Production and Services 12(4):92-104. https:// doi.org/10.2478/emj-2020-0030

Craighead CW, Meredith J (2008) Operations management research: Evolution and alternative future paths. Int J Oper Prod Manag 28(8):710-726. https://doi.org/10.1108/01443570810888625

Dalenogare LS, Benitez GB, Ayala NF, Frank AG (2018) The expected contribution of Industry 4.0 technologies for industrial performance. Int J Prod Econ 204:383-394. https://doi.org/10. 1016/j.ijpe.2018.08.019

Davis MM, Spohrer JC, Maglio PP (2011) Guest editorial: How technology is changing the design and delivery of services. Oper Manag Res 4(1-2):1-5. https://doi.org/10.1007/ s12063-011-0046-6

Dertouzos ML, Lester RK, Solow RM (1989) Made in America

Egghe L, Rousseau R (2006) An informetric model for the Hirschindex. Scientometrics 69(1):121-129

Eisenhardt KM (1989) Building Theories from Case Study Research Published by : Academy of Management Stable. Acad Manag Rev 14(4):532-550

Ellram LM (2013) Offshoring, reshoring and the manufacturing location decision. J Supply Chain Manag 49(2):3-5. https://doi.org/ 10.1111 /jscm. 12023

Elnahass M, Trinh VQ, Li T (2021) Global banking stability in the shadow of Covid-19 outbreak. J Int Financ Mark Inst Money 72. https://doi.org/10.1016/j.intfin.2021.101322

Evans GL (2019) Emergence of a digital cluster in east London: birth of a new hybrid firm. Compet Rev 29(3):253-266. https://doi.org/ 10.1108/CR-08-2018-0047

Fagerberg J, Fosaas M, Sapprasert K (2012) Innovation: Exploring the knowledge base. Res Policy 41(7):1132-1153. https://doi.org/10. 1016/j.respol.2012.03.008

Ferasso M, Beliaeva T, Kraus S, Clauss T, Ribeiro-Soriano D (2020) Circular economy business models: The state of research and avenues ahead. Bus Strateg Environ 29(8):3006-3024. https:// doi.org/10.1002/bse. 2554

Ferrante BK (1978) Bibliometrics: Access in the library literature. Collect Manag 2(3):199-204. https://doi.org/10.1080/J105v02n03_02

Goryachikh SP, Sozinova AA, Grishina EN, Nagovitsyna EV (2020) Optimisation of the mechanisms of managing venture investments in the sphere of digital education on the basis of new information and communication technologies: Audit and reorganisation. Int J 
Econ Policy Emerg Econ 13(6):587-594. https://doi.org/10.1504/ IJEPEE.2020.111692

Goyal S, Chauhan S, Mishra P (2021) Circular economy research: A bibliometric analysis (2000-2019) and future research insights. J Clean Prod 287:125011. https://doi.org/10.1016/j.jclepro. 2020.125011

Guide Jr. VDR, Gunes ED, Souza GC, van Wassenhove LN (2008) The optimal disposition decision for product returns. Oper Manag Res 1(1):6-14. https://doi.org/10.1007/ s12063-007-0001-8

Hines P, Rich N, Bicheno J, Brunt D, Taylor D, Butterworth C, Sullivan J (1998) Value stream management. Int J Logist Manag 9(1):25-42

Hirsch JE (2005) An index to quantify an individual's scientific research output. Proc Natl Acad Sci 102(46):16569-16572

Holmström J, Holweg M, Khajavi SH, Partanen J (2016) The direct digital manufacturing (r)evolution: definition of a research agenda. Oper Manag Res 9(1-2). https://doi.org/10.1007/ s12063-016-0106-Z

Joubioux C, Vanpoucke E (2016) Towards right-shoring: a framework for off-and re-shoring decision making. Oper Manag Res 9(34):117-132. https://doi.org/10.1007/s12063-016-0115-y

Kessler MM (1963) Bibliographic Coupling Between Scientific Papers' Received. J Assoc Inf Sci Technol 14(1):10-25

Kim D-Y (2013) Relationship between supply chain integration and performance. Oper Manag Res 6(1-2):74-90. https://doi.org/10. 1007/s12063-013-0079-0

Kuhn H, Sternbeck MG (2013) Integrative retail logistics: An exploratory study. Oper Manag Res 6(1-2):2-18. https://doi.org/10.1007/ s12063-012-0075-9

Kumar S, Sureka R, Pandey N (2020a) Forty-five years of the International Journal of Social Economics (IJSE): a bibliometric overview. Int J Soc Econ 47(7):831-849. https://doi.org/10.1108/ IJSE-08-2019-0492

Kumar S, Sureka R, Vashishtha A (2020b) The Journal of Heritage Tourism: a bibliometric overview since its inception. J Herit Tour 15(4):365-380. https://doi.org/10.1080/1743873X.2020.1754423

Laengle S, Merigó JM, Miranda J, Słowiński R, Bomze I, Borgonovo E, Dyson RG, Oliveira JF, Teunter R (2017) Forty years of the European Journal of Operational Research: A bibliometric overview. In Eur J Oper Res

Langabeer JR, DelliFraine JL, Heineke J, Abbass I (2009) Implementation of Lean and Six Sigma quality initiatives in hospitals: A goal theoretic perspective. Oper Manag Res 2(1):13-27. https://doi. org/10.1007/s12063-009-0021-7

Liao H, Tang M, Li Z, Lev B (2019) Bibliometric analysis for highly cited papers in operations research and management science from 2008 to 2017 based on Essential Science Indicators. Omega (united Kingdom) 88:223-236. https://doi.org/10.1016/j.omega.2018.11.005

Lifvergren S, Gremyr I, Hellström A, Chakhunashvili A, Bergman B (2010) Lessons from Sweden's first large-scale implementation of Six Sigma in healthcare. Oper Manag Res 3(3-4):117-128. https://doi.org/10.1007/s12063-010-0038-y

Linnenluecke MK, Marrone M, Singh AK (2020) Sixty years of Accounting \& Finance: a bibliometric analysis of major research themes and contributions. Account Finance. https://doi.org/10.1111/acfi.12714

Loh L, Venkatraman N (1992) Diffusion of information technology outsourcing: Influence sources and the Kodak effect. Inf Syst Res 3(4):334-358. https://doi.org/10.1287/isre.3.4.334

Maresova P, Soukal I, Svobodova L, Hedvicakova M, Javanmardi E, Selamat A, Krejcar O (2018) Consequences of industry 4.0 in business and economics. Economies 6(3). https://doi.org/10. 3390/economies6030046

Martínez-Blasco M, Argilés-Bosch JM, García-Blandón J, De Ibarreta M, Zorita C (2016) Factors influencing citations in accounting: an analysis of REFC [Factores influyentes en las citaciones en contabilidad: un análisis de la REFC]. Rev Espanola De Financiacion y Contab 45(4):487-516. https://doi.org/10.1080/02102412.2016.1216815

Martyn J (1964) Bibliographic coupling. J Doc 20(4):236. https://doi. org/10.1108/eb026352

Merigó JM, Muller C, Modak NM, Laengle S (2019) Research in Production and Operations Management: A University-Based Bibliometric Analysis. Glob J Flex Syst Manag 20(1). https://doi.org/10.1007/ s40171-018-0201-0

Meseguer-Sánchez V, Gálvez-Sánchez FJ, López-Martínez G, Molina-Moreno V (2021) Corporate social responsibility and sustainability. A bibliometric analysis of their interrelations. Sustainability (switzerland) 13(4):1-18. https://doi.org/10.3390/ su13041636

Mishra D, Gunasekaran A, Papadopoulos T, Dubey R (2018) Supply chain performance measures and metrics: a bibliometric study. Benchmarking 25(3):932-967. https://doi.org/10.1108/ BIJ-08-2017-0224

Moll J, Yigitbasioglu O (2019) The role of internet-related technologies in shaping the work of accountants: New directions for accounting research. Br Account Rev 51(6). https://doi.org/10.1016/j.bar. 2019.04.002

Moya-Clemente I, Ribes-Giner G, Chaves-Vargas JC (2021) Sustainable entrepreneurship: An approach from bibliometric analysis. J Bus Econ Manag 22(2):297-319. https://doi.org/10.3846/jbem. 2021.13934

Muehlmann BW, Chiu V, Liu Q (2015) Emerging technologies research in accounting: JETA's first decade. J Emerging Technol Account 12(1):17-50. https://doi.org/10.2308/jeta-51245

Neely A (2008) Exploring the financial consequences of the servitization of manufacturing. Oper Manag Res 1(2):103-118. https://doi.org/ 10.1007/s12063-009-0015-5

Noor S, Guo Y, Shah SHH, Saqib Nawaz M, Butt AS (2020) Bibliometric analysis of social media as a platform for knowledge management. Int J Knowl Manag 16(3):33-51. https://doi.org/10.4018/ IJKM.2020070103

Okubo Y (1997) Bibliometric indicators and analysis of research systems: methods and examples.

Olhager J, Shafer S (2018) Editorial: Passing the torch of Operations Management Research. Oper Manag Res 11(3-4):67-68. https:// doi.org/10.1007/s12063-018-0135-x

Oliveira EFS, Luz JRM, de Melo LSA, Cirne GMP, Sampaio FJCS (2018) Strategic management of costs: A bibliometric and sociometric analysis of the scientific production in the period from 2006 to 2015. Custos e Agronegocio 14(3):230-253. https:// www.scopus.com/inward/record.uri?eid=2-s2.0-85056174225\& partnerID $=40 \&$ md5 $=71341958$ ac5d 9 de 3 cbf9d3720d6e $035 \mathrm{a}$

Pao ML (1985) Characteristics of American revolution literature. Collect Manag 6(3-4):119-128. https://doi.org/10.1300/J105v06n03_12

Paule-Vianez J, Gómez-Martínez R, Prado-Román C (2020) A bibliometric analysis of behavioural finance with mapping analysis tools. Eur Res Manag Bus Econ 26(2):71-77. https://doi.org/10.1016/j. iedeen.2020.01.001

Pilkington A, Meredith JR (2018) The diffusion network of research knowledge in operations management. Int J Oper Prod Manag 38(2):333-349. https://doi.org/10.1108/IJOPM-08-2016-0440

Pont GD, Furlan A, Vinelli A (2009) Interrelationships among lean bundles and their effects on operational performance. Oper Manag Res 1(2):150-158. https://doi.org/10.1007/s12063-008-0010-2

Rey-Martí A, Ribeiro-Soriano D, Palacios-Marqués D (2016) A bibliometric analysis of social entrepreneurship. J Bus Res 69(5):16511655. https://doi.org/10.1016/j.jbusres.2015.10.033

Rialp A, Merigó JM, Cancino CA, Urbano D (2019) Twenty-five years (1992-2016) of the International Business Review. A bibliometric 
overview. Int Bus Rev 28(6). https://doi.org/10.1016/j.ibusrev. 2019.101587

Robinson PK, Hsieh L (2016) Reshoring: a strategic renewal of luxury clothing supply chains. Oper Manag Res 9(3-4):89-101. https:// doi.org/10.1007/s12063-016-0116-X

Rolland E, Patterson RA, Ward K, Dodin B (2010) Decision support for disaster management. Oper Manag Res 3(1):68-79. https://doi. org/10.1007/s12063-010-0028-0

Samson D (2020) Operations/supply chain management in a new world context. Oper Manag Res 13(1-2). https://doi.org/10.1007/ s12063-020-00157-w

Samson D, Kalchschmidt M (2019) Looking forward in operations management research. Oper Manag Res. https://doi.org/10.1007/ s12063-019-00138-8

Schulz A-C, Nicolai AT (2015) The intellectual link between management research and popularization media: A bibliometric analysis of the Harvard Business Review. Acad Manag Learn Educ 14(1):31-49. https://doi.org/10.5465/amle.2012.0397

Servantie V, Cabrol M, Guieu G, Boissin J-P (2016) Is international entrepreneurship a field? A bibliometric analysis of the literature (1989-2015) [L'entrepreneuriat international est-il un champ? Une analyse bibliométrique de la littérature (1989-2015)] [¿Es el emprendimiento internacional un campo? Un. J Int Entrep 14(2):168-212. https://doi.org/10.1007/s10843-015-0162-8

Shen H, Fu M, Pan H, Yu Z, Chen Y (2020) The Impact of the COVID19 Pandemic on Firm Performance. Emerg Mark Financ Trade 56(10):2213-2230. https://doi.org/10.1080/1540496X.2020.1785863

Stentoft J, Mikkelsen OS, Jensen JK (2016) Flexicurity and relocation of manufacturing. Oper Manag Res 9(3-4):133-144. https://doi. org/10.1007/s12063-016-0110-3

Talukdar D (2015) Research productivity patterns in the organizational behavior and human resource management literature. Int J Hum Resour Manag 26(4):467-484. https://doi.org/10.1080/09585192. 2011.561218

Tang M, Liao H, Tamasevicius V (2020) 15 years in web of science of the transformations in business and economics: Bibliometric and visual analyses [Verslo ir ekonomikos transformacijos 15 metu web of science duomenų bazeje: Bibliometrinè ir vizualinè analizès]. Transform Bus Econ 19(1):21-42. https://www.scopus.com/inward/ record. uri? eid=2-s2.0-85082684067\& partnerID $=40 \& \mathrm{md} 5=$ a0b3a1e6d2d4896c8b26c9d205dd700a
Wang C, Lim MK, Lyons A (2019) Twenty years of the International Journal of Logistics Research and Applications: a bibliometric overview. Int J Log Res Appl 22(3):304-323. https://doi.org/10. $1080 / 13675567.2018 .1526262$

Wang Q, Sun X (2019) The international journal of production research in the past, the present and the future: a bibliometric analysis. Int J Prod Res 57(15-16):4676-4691

Yadav S, Luthra S, Garg D (2020) Internet of things (IoT) based coordination system in Agri-food supply chain: development of an efficient framework using DEMATEL-ISM. Oper Manag Res. https://doi.org/10.1007/s12063-020-00164-x

Yamaguchi CK, dos Santos APS, Watanabe M (2015) Environmental accounting: A bibliometric study [Contabilidade ambiental: Um estudo bibliométrico]. Espacios 36(11). https://www.scopus.com/ inward/record.uri?eid $=2$-s2.0-84932600019\& partnerID $=40 \&$ md5=bf673fd517f4040241c2b42104e2b915

Zagos A, Brad S (2012) Improvements in patent portfolio valuation with bibliometric indicators. Quality - Access to Success 13(SUPPL.5):451-454. https://www.scopus.com/inward/ record. uri?eid $=2-$ s2.0-84870717517\& partnerID $=40 \& \mathrm{md} 5=$ 58e0857b9b7c8da6566af707196ab7a5

Zeng J, Phan CA, Matsui Y (2013) Supply chain quality management practices and performance: An empirical study. Oper Manag Res 6(1-2):19-31. https://doi.org/10.1007/s12063-012-0074-x

Zha D, Melewar TC, Foroudi P, Jin Z (2020) An Assessment of Brand Experience Knowledge Literature: Using Bibliometric Data to Identify Future Research Direction. Int J Manag Rev 22(3):287317. https://doi.org/10.1111/ijmr.12226

Zhai W, Sun S, Zhang G (2016) Reshoring of American manufacturing companies from China. Oper Manag Res 9(3-4):62-74. https:// doi.org/10.1007/s12063-016-0114-z

Zhang C, Chen Y (2020) A review of research relevant to the emerging industry trends: Industry 4.0, iot, blockchain, and business analytics. Journal of Industrial Integration and Management 5(1):165180. https://doi.org/10.1142/S2424862219500192

Publisher's Note Springer Nature remains neutral with regard to jurisdictional claims in published maps and institutional affiliations. 